„Logopedia Silesiana”, t. 8, ISSN 2391-4297

DOI 10.31261/LOGOPEDIASILESIANA.2019.08.08

(c) BY-SA

\title{
EWA BinkuńsKa
}

Faculty of Languages, Institute of Logopaedics,

University of Gdańsk

(D) 0000-0002-3901-7024

\section{Developmental Tendencies of Articulation of Slit and Compact-slot Sounds in CCV-, -VCC- and -VCC Groups in the Pronunciation of Three-, Four- and Five-year-old Children}

\begin{abstract}
AвSTRACT: The pronunciation of consonant groups in three-, four-, and five-year-old children is an exponent of the acquired phonological competences. A genuine study has to consider the pronunciation of consonants characteristic of specific early stages of speech development. The element of phonetic neighborhood is also an important aspect, being a decisive feature for the final implementation of a specific consonantal connection. In the speech of preschool children, the implementation of consonant groups (CCV-, -VCC- and -VCC), in addition to the pronunciation consistent with the standard one, includes substitutions, reductions, assimilation, and other phenomena, for instance, epentesis. Moreover, there is the coexistence of several types of pronunciation violations of consonant clusters.
\end{abstract}

KEY WORDS: pronunciation of consonant groups, pronunciation of preschool children, speech development

\section{Introduction}

The pronunciation of consonant groups by 3-, 4- and 5-year-olds is an exponent of the phonological competences achieved by that age. These competences may include various skills, e.g. the articulation of individual consonants in isolation or within larger structures, e.g. surrounded by vowels, and later on in consonant clusters ${ }^{1}$. At the same time, in this age group the attempts to pronounce clusters of two, three or more consonants can take on the forms of consonant reduction, substitution, assimilation, or even elision where a given consonant cluster is omitted altogether along with the entire syllable (Barlow, 2003).

${ }^{1}$ In this context, Grażyna Krasowicz-Kupis points out the ability to intentionally manipulate phonemes. An intentional omission of particular sounds is an example of that. 
When studying the articulation of consonant clusters in speech ontogeny, it is important to take into account the level of phonological competence that is characteristic for pre-school children as well as the general development standards concerning the appearance of a given consonant in the child's speech. For example, one ought to consider the palatal articulation of particular consonants, typical for early stages of speech development, An important role in the articulation of consonant clusters is played by the phonological neighbourhood. The phonenes surrounding the sounds that the child has mastered at his or her stage of ontogeny, are decisive for the ultimate articulation of a given consonant cluster.

Beside the above-mentioned processes of substitution, reduction, assimilation, or other processes such as epenthesis, the pronunciation of CCV-, -VCC- and -VCC clusters by preschool children can be characterised by several symptoms of consonant cluster misarticulation occurring at the same time.

\section{Consonant clusters in early speech development}

The process of consonant cluster aquisition in speech ontogeny starts in the second year of one's life - between 18 and 24 months of age - and is preceded by the process of mastering syllables: CV, CVC, VC (Gwozdiew, 2007, p. 105; Zarębina, 1994, pp. 12-18). Consonant clusters can sporadically occur during an earlier stage. Maria Zarębina (1965, p. 19) observed the articulation of individual consonant dyads in infants at the age of about 14-15 months. The author points out the occurrence of a stop consonant in these consonant pairs. In a study published in 1994, The Polish language in an individual's development, Zarębina mentions a case where consonant clusters were absent in the speech of two boys aged $1 y 6 \mathrm{~m}$ and $1 \mathrm{y} 7 \mathrm{~m}$. Then in the fragment marked as a collective text of girls and boys up to the age of 2; 0 the author notes the appearance of the phenomenon of simplifications of consonant groups (1994, pp. 12-20). Zarębina presents the texts in chronological order, so it can be assumed that the last of these statements belong to the group of children aged $1 ; 8$ to $2 ; 0$.

The word item in which consonant clusters appear first is the inter-word, the different order of consonant clusters (Demuth \& Kehoe, 2006, p. 66; Kaczmarek, 1982; Łobacz, 2005, p. 246), e.g. CCV or CVCC, is considered unusual or even accompanying disturbances or disorders related to the process of acquiring communication competences (Zydorowicz, 2010, p. 572). As mentioned, the process of acquiring the pronunciation of consonant groups begins in the second year of the child's life, and their structure is usually noted by the presence of a consonant, nasal or fluent consonant (Łobacz, 2005, p. 244; Zarębina, 1965, pp. 19-33). 
One of the dominant processes, characteristic for the pronunciation of consonant groups in preschool children, are simplifications accompanying the implementation of consonant clusters. Piotra Łobacz, in turn, notes that around the age of seven, abandonments accompanying the pronunciation of consonant groups are rare (Kielar-Turska, 2012, p. 45; Łobacz, 2005, p. 260).

\section{Fundamentals of research methodology}

The purpose of the presented research is to indicate implementation changes occurring in the pronunciation of consonant groups containing slit and dense-slit sounds as well as development trends of proper articulation of preschool children between 37 and 72 months of age. The justification for the research undertaken is the insufficiency of studies on the assimilation of the implementation of consonant groups in speech ontogenesis. A detailed analysis of this phenomenon can be the basis for defining standards for the acquisition of consonant connections, which would be important both in terms of speech therapy and the creation of speech disorder therapy programs.

The research took place in five Tri-City educational institutions and lasted nine months - from October 2016 to June 2017. The research population was 210 children. It was a permanent group recorded once a month. The material constituting the basis of the research were recordings covering four language samples. The first was to name the pictures contained in the developed worksheet containing drawings or photos of designations, whose names had two, three or more elementary consonant groups in the voice, mid-note and sound of the words. Due to the lack of a diagnostic tool to study the implementation of consonant groups (Binkuńska, 2017; Kania, 2001, p. 187; Krajna, 2008, p. 15; Milewski, 2017, p. 272; Przybyla 2013 , pp. $802-809 ; 2015$, pp. 355-362), a picture questionnaire was developed to examine the implementation of consonant clusters. The word material contained therein was collected on the basis of: Vocabulary of preschool children: attendance letters of Halina Zgółkowa (1987)² and Katarzyna Bułczyńska; Dictionary of phonetic variance of contemporary Polish language by Liliana Madelska (2005); The speech therapy collection of words by Janina Wójtowiczowa (1993).

The second attempt was to repeat words. This part of the study uses lexical material that was included in the said questionnaire. Another part of the study

2 At the same time, it should be emphasized that in 2016 a newer study appeared, entitled Vocabulary of preschool children in the years $2010-2015$ by Halina Zgółkowa (2016). However, it was not included because both the preparation of the picture questionnaire and the start of the research took place before the publication of this item. 
was the recording of a conversation of peers of a given kindergarten group, conducted in pairs or in teams of three. The last attempt was to talk to the researcher. Initially, it was a directed conversation, and the pretext was a previously prepared topic related to the child's stay in kindergarten, play, seasons, holidays, etc. If the child-interlocutor changed the subject of the conversation, the investigator abandoned the original subject and allowed for this change.

In this study, the pronunciation of consonant groups was taken into account, which included at least two slotted, dense-slotted sounds, or both.

\section{Phonological basis of data processing}

In order to develop the research results, transcription of children's texts was carried out. The phonological system proposed by Bronisław Rocławski (1986a, pp. 23-24; 1986b, pp. 85-86) was adopted, containing the following consonant

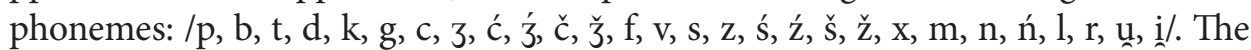
main criterion of the analysis was the identification of slot consonants: $/ \mathrm{f}, \mathrm{v}, \mathrm{s}, \mathrm{z}$, ś, ź, š, ž, x/; and compact-slotted: /c, 3, ć, ź, č, ̌̌/ (Dyszak, Laskowska, \& Święcicka, 1997, pp. 56-61; Rocławski, 1986a, pp. 23-24).

Norms related to the age of children, in which the implementation of specific slot and compact-slot sounds, are adopted on the basis of a study by Małgorzata Bryndal (2015, pp. 100-101). It adopts the criterion according to which the completion of the process of acquiring sounds is evidenced by their occurrence in the value above $90 \%$. Taking into account the processes of assimilation of the implementation of individual slot and compact-slot sounds in speech ontogenesis, it was assumed that the sounds [f, $\mathrm{v}$ ] are absorbed by children belonging to all studied age groups - by three, four and five-year-olds (cf. Dołęga, 2003; Łobacz, 1996, p. 143).

The percentage of learning a consonant [ś] occurs in the population of three-year-old children at the level of $91 \%$ and is the same as in the case of the voice [v]. On this basis, it can therefore be assumed that in the population of three-year-olds the pronunciation of all three of the above-mentioned sounds has been assimilated. However, the process of acquiring the other middlelanguage consonants - slit, voiced [ź] and compact-slit consonants [ć, ź] - has not yet been completed (cf. Kania, 2001, p. 85; Sołtys-Chmielowicz, 1998). This situation draws attention primarily due to the fact that, according to the data presented by Bryndal, the process of noiseless, slotted, middle language consonant acquisition [ś] in the population of children aged three years has already been completed. Acquisition of other middle-language consonants [ź, ć, ź] is completed in the following year of life. 
Four-year-old children are also a group in which the developmentally assimilation of another consonant - slotted, voiceless, pre-lingual-tooth - $[\mathrm{s}]$ is completed, but - as was the case with middle-language sounds - also the implementation of the remaining anterolingual sounds (the so-called hissing series) - a slit and compact-slit consonant, anterolingual-dental consonant $[\mathrm{z}, \mathrm{C}, \mathrm{z}]$ is not yet mastered, one can only talk about the initiated process of assimilation of their normative implementation, while their acquisition is only completed in children who are five years old. Acquisition of the remaining slit and compact-slit sounds gingival - begins in the said age group, and ends in the group of six-year-olds (Bryndal, 2015, p. 100; Krajna, 2002, p. 35).

The process of assimilation of individual sounds is progressive and is associated with the maturation of communication, motor and hearing skills (Bee, 2004, pp. 200-203; Porayski-Pomsta, 2015, p. 139, 152). However, age limits are difficult to clearly define in this case (cf. Czaplewska, 2012, p. 91). One of the common features of these sounds, taking into account the results of Bryndal, is faster control in the case of these middle-language, language-tooth and gingival sounds, three slit, voiceless - [ś], [s] and [̌s] - a only later the other sounds of the given series, and therefore the consonant [ś] is mastered first, then [ź, ć, ź], the assimilation of realization $[s]$ precedes the pronunciation $[\mathrm{z}, \mathrm{c}, 3]$, and acquisition $[\check{s}]$ occurs earlier than $[\check{z}, \check{c}, \check{z}]$.

On the other hand, the last, the most difficult sound in the case of middlelingual and anterolingual-dental teeth turned out to be the absorption of voiced compacto-fissile sounds [3] and [3], while in the case of gingival consonants, the most difficult in ontogenesis was the voiced, fissile sound [ž]. However, a certain kind of consistency can be observed in the case of the absorption of compactslot, voiceless sounds [ć, c, č]. The process of their assimilation proceeds simultaneously with the absorption of the voiceless consonant, however, the acquisition usually ends when the structuring of the pronunciation of the first of these sounds occurs (cf. Bryndal, 2015, p. 101).

\section{The process of acquiring consonant groups against the background of assimilation of consonants' implementation}

However, the data presented above regarding the completion of the acquisition of specific consonants do not refer to their implementation in consonant groups (Milewski, 1999, pp. 136-140; 2005, p. 6). Stanisław Milewski states that the violation of the structure of consonant connections is accompanied by the pronunciation of children in their sixth or even seventh year - and thus when 
slit and slit consonants are already implemented in accordance with the pronunciation norm (cf. Czaplewska, 2012, p. 91). Thus, in the implementation of consonant groups, after the end of the period in which the pronunciation of individual sounds occurs, violations occur, e.g. in the form of reduction, are still observed.

Significant differences regarding the absorption of consonants in consonant clusters against the background of their implementation in the vowel neighborhood indicate that it is the consonant neighborhood that is the specific condition that determines the appearance in children's speech of modifications such as simplifications, similarities, substitutions, epenteses, etc. An example of this type of phenomenon is the acquisition of sounds [f], [v], [s], [z]. The pronunciation of these consonants is mastered fairly early. The voices [f] and [v] can be considered already adopted in the population of three-year-olds. Acquisition of consonant [f] in the vicinity of a vowel is $94 \%$, while [v] - 91\%. However, in consonant groups, taking into account the pronunciation of three-year-old children, the voice [f] was adopted in $66 \%$ of realizations, while [v] - 50\%. Therefore, when comparing the implementation of these consonants in consonant combinations and their pronunciation in the vicinity of the vowel in particular age groups, the differences are significant.

Also [s] and [z] have a fairly high acquisition rate when sounds occur outside consonant groups. The consonant compound, especially if it consists of sounds with the same articulation features, e.g. the same manner of articulation (in this case, slit consonants, but also e.g. voiced), constitute a context conducive to the occurrence of such phonetic phenomena, e.g. simplifications . Hence the common pronunciation in the population of three-year-olds: /zul/ instead /vzul/ or /vzur/ 'formula'; /sxut/ instead /fsxut/ 'east'. The largest differences in the assimilation of individual consonants appearing in the vowel neighborhood and in a consonant cluster occur just in the population of three-year-old children and amount to even $41 \%$ in the case of the consonant [v], 31\% when considering the voice [ś], $28 \%$ in pronunciation [f]. 


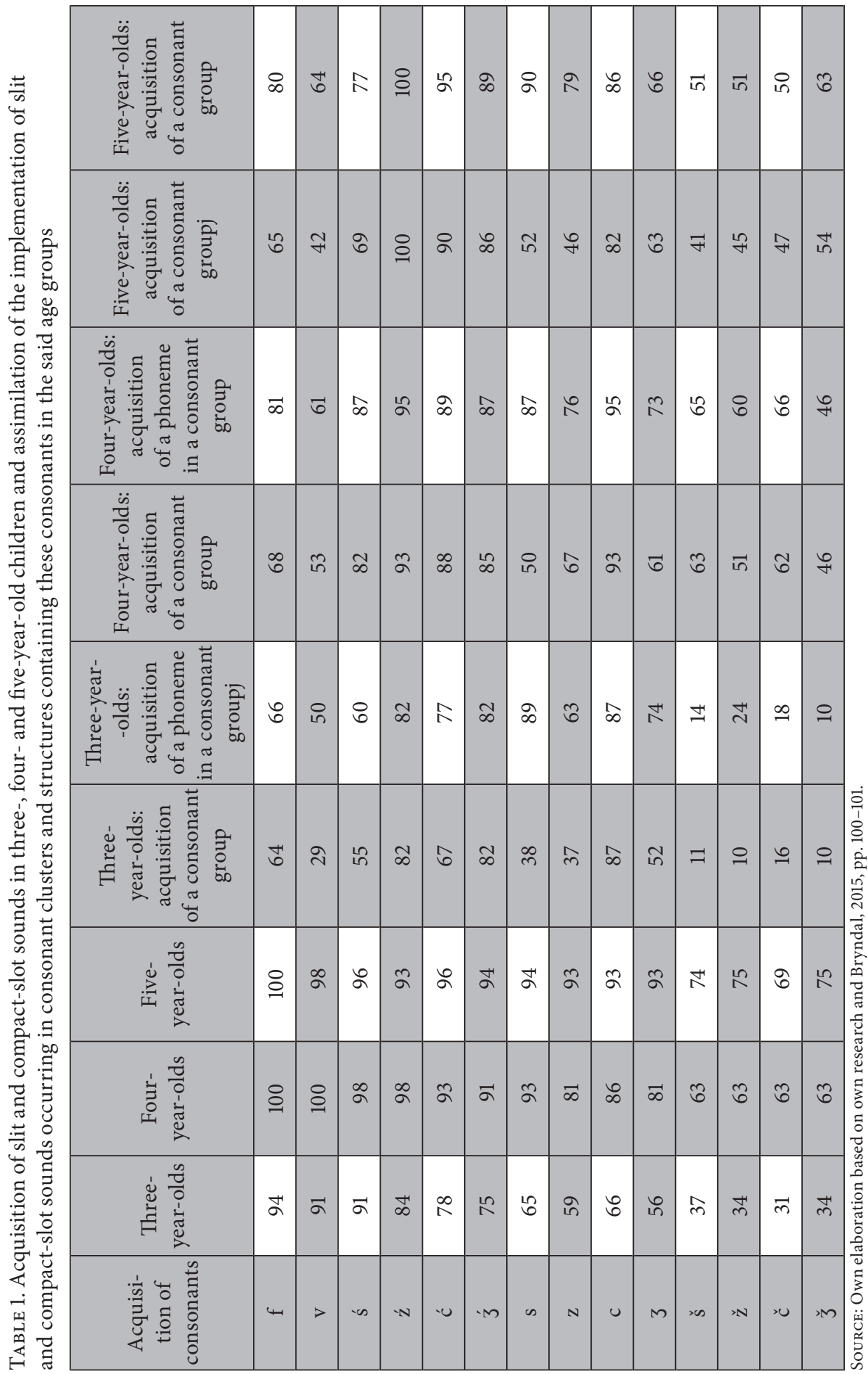




\section{Consonant groups containing slit and slit consonants in the implementation of three-year-old children}

One of the phenomena that can be most often observed in the implementation of consonant groups containing slotted and dense-slotted sounds in a group of three-year-old children is the reduction of sounds included in consonant clusters. Here are examples of this kind of implementation: /zul/ 'pattern', /sufka/ 'wsówka', /zońi/ 'dzwoni', /zonki/ dzwonki, An example of simplification occurring within a three-member consonant group may be the combination: /śfii-/. Most often the consonant group /śfí-/ was reduced to a single phoneme: /ś-/ - /śećnik/, /śeca/; /ć-/ - /ćeca/, but it also appeared in the form of diadas /fi-/ - /fiećníik/, /fieca/, /fiećki/. There was also a pronunciation with an anterolingual tooth sound [s-] /sieca/ (Milewski, 1998, p. 187).

Simplifications of consonant clusters concerned a large group of words. In addition to the aforementioned units, such as: 'candle' - pronounced as /síieca/, 'candlestick' - /śiećńik/, the phenomenon of reduction also often appeared in the following lexemes: "induced" implemented as /buzone/, /zbuzone/; 'Wzbija się' /zbiiia śę/; 'Wejie' - /veićé/. Reductions of consonant connections also occurred

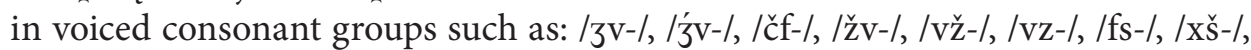
/vzb-/, /vzm-/, /fsp-/.

In the group of three-year-old children, in many lexical units, simplification of consonant clusters was accompanied by substitution. In most implementa-

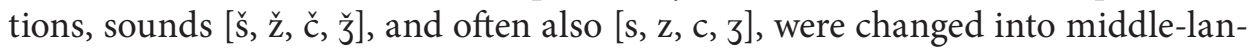
guage consonants appearing earlier in speech ontogenesis [ś, ź, ć, ź] (cf. SołtysChmielowicz, 2005, p. 459). For example, in the analyzed material, the word zbonka consonantyczna /šč-/, consisting of anterolingual-gingival, fissure and compacted-fissile sounds, was implemented as [ć], less often [c], and sporadically [č]. Examples in this case are the following words: 'szczypiorek' - /ćipiolek/, /cypiolek/, (rarely - /čypiolek/); 'puppy' - /ceńak/; 'szczupak' - /cupak/; 'rat' /cul/. In turn, an example of the coexistence of simplification together with substitution within a voiced consonant triad is the neighborhood, e.g. [pšč-], which, undergoing reduction, was implemented as [c-] or [pc-]. Therefore, three-year-old children pronounced the words: /couna/ or /pcouna/ in this case.

The implementation of a large group of words contained substitutions involving sounds included in consonant connections (Sołtys-Chmielowicz, 2008, pp. 137-139). The most common phonemes / ̌s, $\check{z}, \check{c}, \breve{z} /$ and /s, z, c, z/ were exchanged, but there were also substitutions /ś, ź, ć, źl. An example of this kind of implementation is both the aforementioned pronunciation of the words 'puppy' as /s shut-up/, 'szczupak' as /scupak/ or 'savings' as /oscenza/, but also /sfinka/ 'śfinka', /3vik/, 'dźisk'.

Another phenomenon that occurred in the pronunciation of three-year-old children was the epenthesis consisting in the expansion of a consonant group by 
a slotted or slotted-tone sound, e.g. / - /vzvil/, /sps/ - /spsouna/, /ssf-/ - /ssfonki/. ${ }^{3}$ These types of realizations are an example of the appearance in the pronunciation of three-year-old new groups that do not appear in Polish (Milewski, 2005, p. 17).

The pronunciation of three-year-old children in the case of clusters of voiced slotted consonants /vz-/ was most often accompanied by a reduction, the abovementioned epenthesis also appeared, there was also a breakup of a consonant group by adding a vocal element, e.g. in the word /z (y) sul/ 'pattern', and modification in the order of pronounced consonants: /vz-/ /zvul/; also their voicing and place of articulation /s-/, /syzul/; whether the expression 'arouses admiration'/zybua/, in which in the case of the triad /vzb-/ apart from the reduction of the first element there was an epenthesis - the vocal element /y/ broke adjacent consonants $[\mathrm{z}]$ and $[\mathrm{b}]$. In the pronunciation of three-year-old children, the epenthesis consisting in the use of both an additional consonant and a vowel was not a common phenomenon. This type of linguistic phenomenon could be observed to a greater extent in the realizations of four-year-olds.

In a small group of words, there was also a simplification of the voice. It occurred in the form of the lack of implementation of the entire consonant group, e.g. /vž-/, in the lexical unit 'spindle' implemented as /ećona/ - in this case there was also a change of the inflectional form or the entire syllable was reduced, e.g. /ćono/.

\section{Consonant groups containing slit and slit consonants in the implementation of four-year-old children}

In the group of four-year-old children, compared to the population of threeyear-olds, the phenomenon of simplification of consonant groups containing slotted and compact-slotted sounds occurs less frequently. ${ }^{4}$ Among four-yearolds, the reduction of consonant connections, which contain the consonants in question, mainly concerns such lexical units as: 'heather' implemented as /žos/, 'climbs' as /spin/, 'agitated' as /zbuzone/ or /buzone/5, 'wsuwka' as /sufka/, 'east' as /sxut/, 'bells' as /vonki/, 'szczupak' as /šupak/, 'bee' as /pčoưa/, /pšouna/ or /čouna/, 'earthworm' as /క̌ovńica/, 'entrance' as /eiće/ and 'deszcz' as /deš/. In addition to the reduction occurring within a consonant group, there are also reductions of a syllable containing a consonant cluster, e.g. pronunciation of the word 'chives' as /polek/ or /spiolek/.

${ }^{3}$ Cf. Łobacz, 2005, p. 248; Zarębina, 1965, p. 91. They note that the consonant [s] appears in consonant groups quite early.

${ }^{4}$ A similar tendency persists in the group of five-year-olds.

${ }^{5}$ In the group of four-year-olds, correct implementation has also repeatedly occurred /vzbužone/. 
Substitution is the dominant phenomenon in the group of four-year-old children. It also applies to consonants included in consonant clusters. Examples illustrating the process may be the words: /s termak/ 'puppy', /zvil/ 'żwir', /scypiolek/, /śćipiolek/ 'szczypiorek', /pscouna/ 'bee', /vzescy/ 'wrzszczy', /des/ 'rain' (Milewski, 1998, pp. 184-185; 2001, pp. 232-233). Occasionally, in this age group, substitution appears, which is also a hyper-correct realization of slit or compact-slit sounds, e.g. in the 'vik 'vik reference book pronounced /vik/. The co-occurrence of substitution and reduction phenomena mainly concerns the combination of consonants [šč-] both within the diadas and the consonant triads /śul/ 'rat', /osenza/ 'savings', as well as 'bee' /psouna/.

The epenthesis appearing in the pronunciation of four-year-old children, taking into account consonant groups containing slotted and dense-slotted sounds, most often appeared in the voice and consisted of adding a consonant element. Such a situation took place e.g. in the word 'bee' implemented as /fpčouna/ or 'pattern' as /sscul/. In some words - just like it was in the pronunciation of threeyear-old children - the vowel was added. As a result of this phenomenon, the consonant group was broken up. Such a situation is found in the word /tefurka/ 'quartet' - in this case there was additionally a substitution of the voice [č $]$ converted into the consonant $[\mathrm{t}]$.

Another way to violate the implementation of consonant groups is by alignment. Particular difficulty - as in the case of three-year-olds - was caused by the pronunciation of a consonant cluster by four-year-old children, which consisted of crevice and compact-crevice sounds, gingival: [šč-]. This situation related to the words: 'bee' implemented as /ssouna/, 'szczypiorek' - /ssypiolek/, 'szczupak', /sśupak/ or /skupak/.

\section{Consonant groups containing slit and slit consonants in the implementation of five-year-old children}

The process of reducing consonant connections occurring in a group of fiveyear-old children concerned specific words. They were, for example, such lexical units as: 'earthworm' often implemented as /žovńica/, 'soars' as /zbiia śę/, 'amplifier' as /zmacńač/, 'climbs' as /spinna/, 'wsuwka' as /sufka/, 'spindle' pronounced as /žećono/, 'east' as /sxut/, 'dzwonek' /vonek/; 'szczypiorek' /čypiorek/; 'pszczoła' as /pčouna/, /pšouna/ or /čouna/, 'zamirzenie' być /zbužone/. The most-overlooked consonants were fissure, labial-tooth [v] and [f].

The phenomenon of substitution is still observed in the pronunciation of fiveyear-old children. Considering the realizations of the slotted and dense slotted sounds analyzed in this study, it mainly concerns the replacement of consonants 
$[\check{s}, \check{z}, \check{c}, \check{\zeta}]$ and occurs in a large group of words, and the following lexical units can be cited as an example of this language process: 'sparing' /oscenza/, 'wrzszczy' /vzescy/, 'owca' /ofsa/, 'szczypiorek' /scypionek/, 'kłik' /dvik/, 'żwir'/zvil/, 'szczupak' /sčupak/ or more often /scupak/, as well as 'dzwoni'/zunońi/. In some words, the replacement of consonants takes on the character of hyper-correctness. This happens in the words: 'bell' pronounced as /žvonek/ and 'demolished' implemented as /žbužone/. In the latter case, hyper-correctness is most likely the result of a similarity, consisting in changing the place of articulation from the anterolingual-dental characteristic of the sound $[\mathrm{z}]$ to the anterolingual-gingival characteristic of the consonant [ž].

The coexistence of language processes such as substitution and reduction applies to a small group of words in this population. They are: 'wrzos' pronounced as /zos/, 'wrzeciono' as /zećono/, 'bee'/psouna/, 'szczupak'/cupak/. The processes of simultaneous substitution and reduction were observed in consonant groups composed of two sounds with the same manner of articulation [vž-] and having the same feature of voicing; and also in the group [šč-], in which soundless realization is also a common feature, these consonants also have the same gingival place of realization, while one of them is slit-like, the other compact-slit.

Other less common occurrences are reduction and hyper-accuracy in the implementation of the word 'bone' as /koš/; the change of the place of articulation from the labial-tooth to the labial one appearing five times in the collected material in the words 'herzos' /bžos/ - the word was thus implemented three times; and /bžećono/ - twice. Untypical substitutions can also include the pronunciation of the word 'szczupak' as /skupak/. The change in the place of articulation from the gingival realization characteristic for the sound [č to the rear language [k] is specific here - nevertheless the consonant / sk group formed as a result of this process is one of the most common in Polish (Śledziński, 2010, p. 69). The second example is the three-fold pronunciation of the lexeme 'bells' as /zvonki/ with the change of a slotted and slotted sound.

\section{Comparative quantitative analysis covering the implementation of slotted and compact-slot sounds in a group of three-, four- and five-year-old children}

In the analyzed age group, the reduction belonged to the dominant phenomena that appeared in the onset of words. It occurred in $43 \%$ of lexemes. Substitutions appearing in the unreduced consonant group concerned $21 \%$ of the implementation, while the reduction co-occurring with the substitution 
was observed in $18 \%$ of the words. However, these proportions change in the mid-echo and the voice-over, where substitutions of consonants become the dominant process.

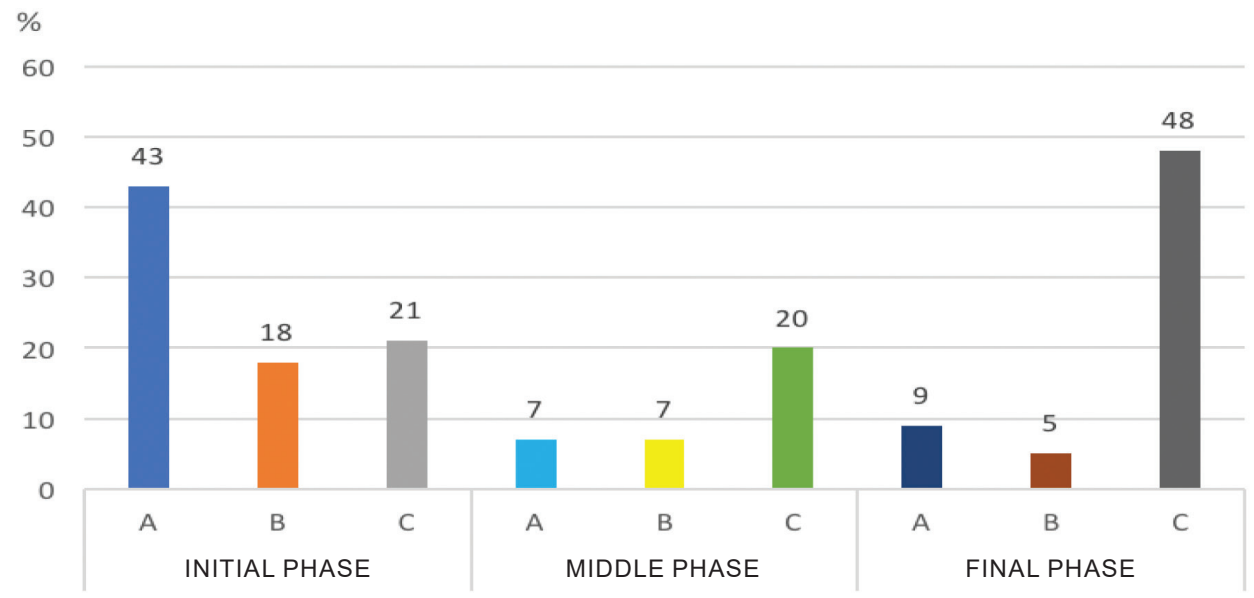

FIGURE 1. Processes characteristic of the implementation of consonant groups containing slotted and dense-slotted sounds in the voice, mid-voice and sound in the group of three-year-old children

A - reductions occurring within the group of slot and/or compact-slot consonants

$\mathrm{B}$ - coexistence of substitution and reduction of slit and/or dense slit sounds in a consonant group $\mathrm{C}$ - substitution of sounds occurring within the implemented group of slit and/or slit-consonants SOURCE: Own study.

In the pronunciation of consonant groups in the population of four-year-olds, a significant percentage decrease is observed in the words in which the consonant groups occurring in the letter are reduced. On the other hand, the substitution of sounds included in consonant connections is becoming the dominant phenomenon. The process as dominant applies to both the position of the voice, mid-voice and sound (chart 2).

In the population of five-year-old children, next to the increasingly rare nonnormative realization of words containing consonant groups in their structure, a similar result of substitution is observed in all positions in the lexical unit. On the other hand, the phenomenon of exchanging sounds was $13 \%$ of lexemes, in the mid-voice $-11 \%$, and in the voice $-12 \%$. The frequency of simplification of consonant groups and substitution appearing in the beginning of words has reached a similar value. Thus, the first of the processes took place in the case of $11 \%$ implementation, the second - as mentioned earlier - in 13\% (chart 3). 
$\%$

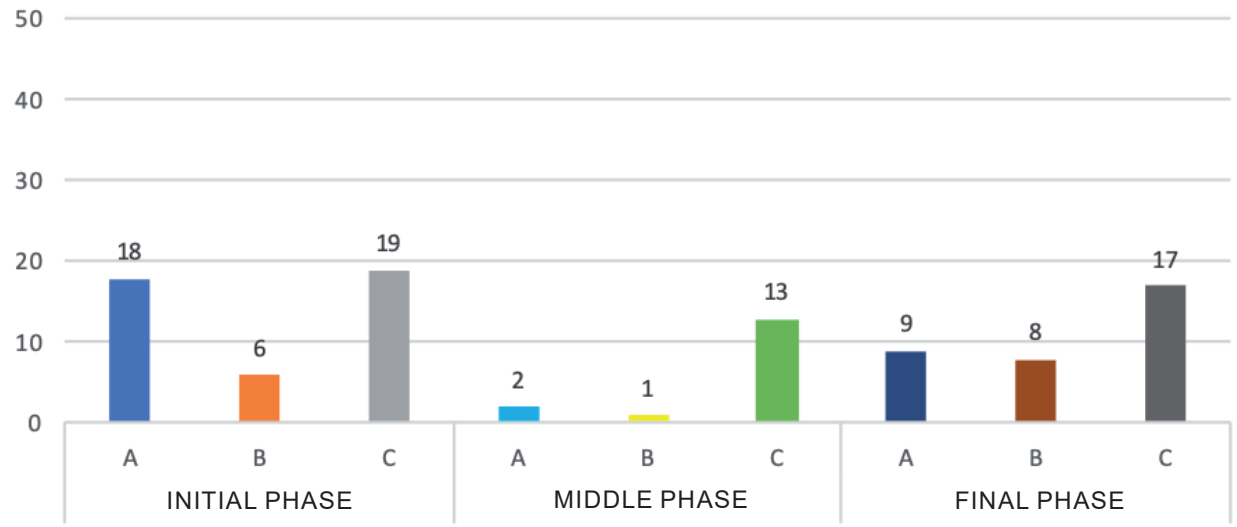

FIGURE 2. Characteristic processes for the implementation of consonant groups containing slotted and dense-slotted sounds in the voice, mid-voice and sound in the group of four-year-old children

A - reductions occurring within the group of slot and/or compact-slot consonants

$\mathrm{B}$ - coexistence of substitution and reduction of slit and/or dense slit sounds in a consonant group $\mathrm{C}$ - substitution of sounds occurring within the implemented group of slit and/or slit-consonants SOURCE: Own study.

$\%$

50

40

30

20

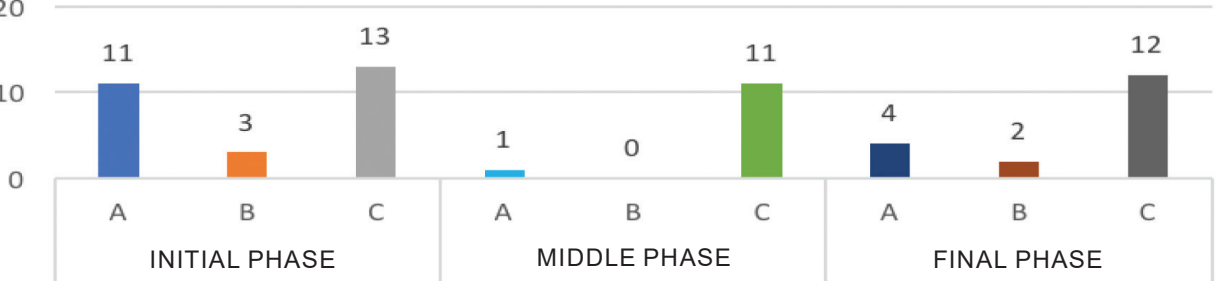

FIGURE 3. Processes characteristic for the implementation of consonant groups containing slotted and compact-slotted sounds in the voice, mid-voice and sound in the group of five-year-old children

A - reductions occurring within the group of slot and/or compact-slot consonants

$\mathrm{B}$ - coexistence of substitution and reduction of slit and/or dense slit sounds in a consonant group $\mathrm{C}$ - substitution of sounds occurring within the implemented group of slit and/or slit-consonants SOURCE: Own study. 


\section{A comparative qualitative analysis of the implementation of consonant groups containing slotted and compact-slotted sounds in the pronunciation of three-, four- and five-year-old children}

Certainly the most correct implementation of consonant groups was observed in the group of five-year-old children. However, considering the qualitative aspect of the changes that occurred in the pronunciation of consonant connections, the group of four-year-olds is surprised by the diversity of implementations of the same consonant group, e.g. a /śfi/ cluster in the word 'candles' for 21 implementations, it was pronounced 8 times in accordance with the norm /śfiečki/, while in the remaining 13 implementations the following ways of its violations appeared: /ś/ - /śecki/, /śi - - /śsiecki/, /śiečki/, /fí-/ - /fiecki/, /sfi-/ - /sfiecki/ (por. Milewski, 2005, p. 16). In the word 'chrząszcz' the initial consonant group /xš-/ was pronounced as /xš-/, /kš-/, /xs-/, /kš-/, /s-/, /ś-/; in turn a /šč-/ cluster appearing in the sound was realized as /-šč/ and /-sc/, /-šč/, /-̌̌l, /-c/, /-nč/, /-ńć/; in this way the following words were created in the pronunciation of four-year-old children: /sąsc/, /kšąšč/, /xsąsc/, /xšąč/, /xsąc/, /kšonč/, /xšąǎl, /śońć/ (Milewski, 1998, p. 182). The consonant group / $/ \check{3}$-/ appearing in the word 'worm' was realized

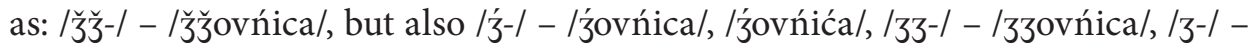
/zovńica/, /ž-/ - /žovńica/, /d-/ - /dovńica/, /క̌-/ - /క̌ovńica/. In the group of fouryear-olds, 9 different implementations were observed in the pronunciation of the triad consonant /pšč-/ appearing in the word 'bee'. They were: /pš-/ - /pšouna/, /sc-I - /scouna/, /pč-/ - /pčouna/, /psc-/ - /pscouna/, /ps-/ - /psouna/, /ss -/ - /ssouna/, /pc-/ - /pcouna/, /fpč-/ - /fpčouna/, /č-/ - /čouna/.

For comparison - in the pronunciation of three-year-old children was noted in the case of the word 'candles' in addition to the correct implementation /śfi/ (Śledziński, 2013, pp. 69-70) also /fí-/, /śi-/, /fai-/, /si-l, /šfi-/, /ć-/, in the lexeme 'chrząszcz' in the title - /s-/, /sc-/, /xs-/, /ks-/, in turn in the pronouncement /-sc/, /-s/, /-c/: /sąsc/, /scąs/, /xsąsc/, /sąc/, /xsąs/, /ksąsc/. In the word 'earthworm' there was never once the correct implementation of the group containing geminata

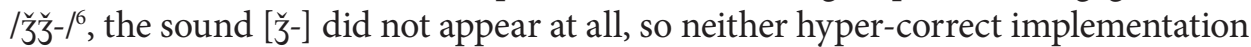
in the form of diadem $/ \check{3} \breve{z}$-/ or simplification / $\check{z}-/$. In the position of voices, the following consonants appeared in the place of her occurrence: /3-/ - /zovnica/, /zonńica/, /c-/ - /cańica/, /cofńica/, /ź-/ - /źivńica/. In the word 'bee' the following realizations of the triad consonant /pšč-/: /c-/, /pc-/, /pč-/, /psc-/, /pšc-/, /sps-/, /špš-/ appeared.

${ }^{6}$ The normative implementation of geminat consists in the extended articulation of the consonant that creates geminate, while in the case of words 'dżdżownica', 'dżdżysty', 'czczy' pronunciation in accordance with the record, i.e. a double consonant, is common (Dunaj, 2006, s. 169). 
In the group of five-year-olds, in the pronunciation of the lexeme 'candle', in addition to correct implementation, also appeared: /śi-/, /sfi-/, /šfi-/. The title of the word 'chrząszcz' was implemented as: /xs-/, /č-/, /xč-/, /kš-/, /xš-/, /̌s-/, /šš-/, /s-/; the ending positions of /-s/, /-š/, /-šč/, /-sš/, /-sc/; in the lexemes: /xsąs/, /xsąš/, /čąščc/,

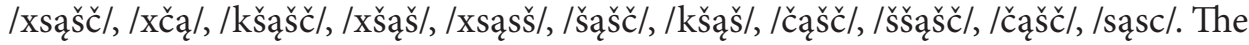
word 'worm' was pronounced, for example: - /亏̌-/ - /亏̌ovńica/, /z-/ - /zovńica/, /క̌yž-/ - /క̌yžovńica/. On the other hand, the following group realizations appeared in the title of the lexeme 'bee': /pč-/, /pś-/, /šč-/, /pš-/, /psc-/, /špšč-/ (table 2).

TABLE 2. Consonant groups containing slit and compact-slit consonants in the pronunciation of three-, four- and five-year-old children

\begin{tabular}{|c|c|c|c|}
\hline Word & $\begin{array}{c}\text { A consonant group } \\
\text { pronounced by three-year- } \\
\text {-old children }\end{array}$ & $\begin{array}{c}\text { A consonant group } \\
\text { pronounced by four-year- } \\
\text {-old children }\end{array}$ & $\begin{array}{c}\text { A consonant group } \\
\text { pronounced by five-year- } \\
\text {-old children }\end{array}$ \\
\hline 'świeczka’ & /fi-l, /śi-I, /si-l, /ć-I, /šfi-/ & /ś-I, /śí-I, /fị-I, /sfí-/ & /śi-I, /sfi-l, /šfi-l. \\
\hline 'chrząszcz' & $/ \mathrm{s}-1, / \mathrm{sc}-1, / \mathrm{xs}-/, / \mathrm{ks}-/$ & /kš-l, /xs-I, /kš-I, /s-I, /ś-/; & 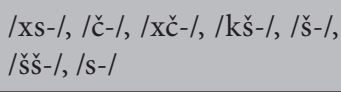 \\
\hline 'chrząszcz' & |-sc/, /-s/, /-c/, & |-scl, |-čl, |-cl, |-nčl, |-ńćl & |-s/, |-šs/, |-š̌s/, |-sc| \\
\hline 'dżdżownica’ & /3-l, /c-l, /3́-1 & 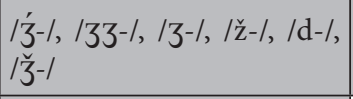 & 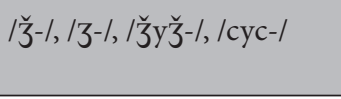 \\
\hline 'pszczoła' & $\begin{array}{l}/ \mathrm{c}-/, / \text { pc- } /, / \text { pč-l, /psc-l, } \\
/ \mathrm{pšc}-/, / \text { sps- } /, / \text { špš- } /\end{array}$ & 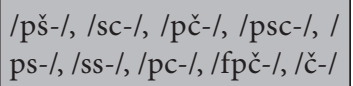 & $\begin{array}{l}\text { /pč-l, /pś-/, /ščl, /špšč/, } \\
/ \mathrm{psc} / / \mathrm{pš} /\end{array}$ \\
\hline
\end{tabular}

SOURCE: Own study.

The pronunciation of four-year-old children is characterized by the greatest diversity in the phenomena occurring within one consonant group in the same lexical unit. The occurrence of various phenomena can be observed in the said population - simplifications, substitutions, hyperprivacy, epenthesis, but also the co-occurrence of the mentioned processes. Diversity also applies to individual phenomena, e.g. simplification of the consonant group /pšč-/ occurs in the population of three-year-olds in the form: /c-/, /pc-/, /pč/, in four-year-olds: /pš-/, /sc-/, /pč-/, /ps-/, /ss-/, /pc-/, /č-/, while in the case of five-year-old children it is only: /pč-/, /pś-/, /ščl, /ps/. Similarly, when analyzing the substitutions appearing in the lexical material, the most diverse conversions of a specific voice to another one appeared in the pronunciation of four-year-old children. For example, geminata $/ \breve{s}_{3} \mathrm{~s}-/$ in a group of three-year-olds was implemented as $/ 3-/$, /c- $/$, $/ 3-/$, in the population of five-year-old children as /3-/, /c-/, while four-year-olds pronounced instead of a voice [ž] both [ź], [3], [ž] and [d]. This number of varied implementations appearing within the discussed consonant groups is additionally increasing when one takes into account the phenomena accompanying the mentioned substitution or the simplification of consonant groups discussed above. 
Analyzing the pronunciation methods of consonant groups, it is noticed that in the case of the words 'candle' or 'bee' in the implementation of consonant triads, there are differences regarding both which voice in the word is simplified by the child and other accompanying language phenomena. Some repetitive ways of pronunciation of consonant triads are observed, however, individual simplifications can also be observed (Barlow, 2005, p. 675). Earlier studies on the pronunciation of consonant groups indicated some kind of preference for reduction and so, for example, German-speaking children pronounce the first consonant in the word, while those speaking in Spanish - the second (Lleó \& Prinz, 1996, p. 37). In the case of consonant groups /śfi-/ and /p̌šc-/ the first consonant in the triad was the most pronounced consonant.

\section{Conclusion}

Analyzing the results of the presented research, one can notice several phenomena occurring in the language development process of three-, four- and five-year-old children. The significant difference between the implementation of consonant groups in the youngest age group and in the case of both older groups is noteworthy. This applies especially to the number of consonant elements pronounced by children. Therefore, in the case of three-year language users, the reduction process seems to be the dominant phenomenon - in the presented research this becomes particularly noticeable in the headline (Table 3).

Also noteworthy are the alignment of results with regard to substitution and simplification of pronunciation of consonant groups in the case of four and fiveyear-olds. The phenomenon here becomes particularly noticeable in the position of the voice. Another phenomenon is the equalization of the results in terms of the percentage occurrence of substitution in a group of five-year-old children, which may indicate a growing awareness and consequence of the implementation of specific sounds in this population.

It is also worth paying attention to the number of consonant groups implemented correctly in each age group. Consonant epithelial complexes in a group of three-year-old children in accordance with the normative pronunciation for the Polish language were implemented by $15 \%$ of the population - and it should be emphasized that substitution of fissile and dense fissile sounds occurring in this age group, pre-lingual-gingival and pre-lingual-dental teeth, such as $[\check{s}, \check{z}, \check{c}, \breve{z}]$ and $[s, z, c, 3]$. In the population of four-year-old children, consonant connections according to the language norm were pronounced by $53 \%$ of people, while in the group of five-year-olds $71 \%$. On the other hand, smaller differences are observed in the way the mid-note and the sound are implemented. 
According to the language norm, in the group of three-year-old children consonant complexes containing the proximity of crevice and dense-crevice sounds pronounced $49 \%$, in the population of four-year-olds $-77 \%$, and among fiveyear-olds $-86 \%$. In the words $26 \%$ of three-year-olds carried out consonant connections in accordance with the language norm. In the group of four-yearolds this situation took place in the case of $53 \%$ of respondents, in the group of five-year-olds it was $72 \%$.

TABLE 3. Processes occurring in the implementation of consonant groups containing slotted and compact-slotted sounds in the voice, mid-voice and sound in the group of three-, four- and five-year-old children

\begin{tabular}{|l|c|c|c|c|c|c|}
\hline & Three-year-olds & & Four-year-olds & & Five-year-olds & \\
\hline Initial phase & & & & & & \\
\hline A & 299 & & 599 & & 653 & \\
\hline B & 62 & $21 \%$ & 114 & $19 \%$ & 87 & $13 \%$ \\
\hline C & 53 & $18 \%$ & 35 & $6 \%$ & 17 & $3 \%$ \\
\hline D & 129 & $43 \%$ & 109 & $18 \%$ & 71 & $11 \%$ \\
\hline Mid-phase & & & & & & \\
\hline A & 122 & & 276 & & 290 & \\
\hline B & 25 & $20 \%$ & 37 & $13 \%$ & 33 & $11 \%$ \\
\hline C & 9 & $7 \%$ & 2 & $1 \%$ & 0 & $0 \%$ \\
\hline D & 44 & & 6 & $2 \%$ & 4 & $1 \%$ \\
\hline Final phase & 21 & $48 \%$ & 15 & $17 \%$ & 10 & $12 \%$ \\
\hline A & 2 & $5 \%$ & 7 & $8 \%$ & 2 & $2 \%$ \\
\hline B & $9 \%$ & 8 & $9 \%$ & 3 & $4 \%$ \\
\hline C & & & & & & \\
\hline D & & & & & 82 & \\
\hline
\end{tabular}

Source: Own study.

An important phenomenon also seems to be the aforementioned productivity of four-year-olds, which consists in accompanying the implementation of consonant clusters of different phenomena and the coexistence of several processes simultaneously, which is one of the important aspects characteristic of the pronunciation of children in this age group. 


\section{Bibliography}

Barlow, J.A. (2003). Asymmetries in the Acquisition of Consonant Clusters in Spanish. Canadian Journal of Linguistics / Revue canadienne de linguistique, 48(3/4), 179-210.

BARLOW, J.A. (2005). Phonological change and the representation of consonant clusters in Spanish: A case study. Clinical Linguistics \& Phonetics, 19(8), 659-679.

BeE, H. (2004). Psychologia rozwoju człowieka (J. Gilewicz, \& A. Wojciechowski, Trans.). Poznań: Wydaw. Zysk i S-ka.

BinKUŃSKa, E. (2017). Grupy spółgłoskowe w logopedycznych próbach diagnostycznych. In: S. Milewski, K. KaczorowsKa-Bray, \& B. Kamińska (Ed.), Studia logopedyczno-lingwistyczne. Ksiegga jubileuszowa z okazji 70-lecia urodzin Profesora Edwarda Łuczyńskiego (pp. 295-311). Gdańsk: Harmonia Universalis.

Bryndal, M. (2015). Fonologiczna interpretacja procesów doskonalenia wymowy dziecięcej na tle współczesnych teorii fonologicznych. Gliwice: Wydaw. Komlogo Piotr Gruba.

Czaplewska, E. (2012). Diagnoza zaburzeń rozwoju artykulacji. In: E. Czaplewska, \& S. MilewSKI (Ed.), Diagnoza logopedyczna. Podręcznik akademicki (pp. 65-120). Sopot: Gdańskie Wydaw. Psychologiczne.

Demuth, K., \& Kenoe, M. (2006). The Acquisition of Word-final Clusters in French. Catalan Journal of Linguistics, 5, 59-81.

DoŁęGA, Z. (2003). Promowanie rozwoju mowy w okresie dzieciństwa-prawidłowości rozwoju, diagnozowanie i profilaktyka. Katowice: Wydaw. Uniwersytetu Śląskiego.

DunaJ, B. (2006). Zasady poprawnej wymowy polskiej. Język Polski, LXXXVI, 161-172.

Dyszak, A., Laskowska, E., \& Święcicka, M. (1997). Fonetyczny i fonologiczny opis współczesnej polszczyzny. Skrypt dla studentów filologii polskiej. Bydgoszcz: Wydaw. Uczelniane Wyższej Szkoły Pedagogicznej.

Gwozdiew, A.N. (2007). Woprosy izuczenija dietskoj reczi. Moskwa: Izdatielstwo Akademii Pedagogiczeskich Nauk.

KaCZMAReK, L. (1982). Nasze dziecko uczy się mowy. Lublin: Wydaw. Lubelskie.

KAnia, J.T. (2001). Szkice logopedyczne. Lublin: Polskie Towarzystwo Logopedyczne. Zarząd Główny.

Kielar-Turska, M. (2012). Rozwój sprawności językowych i komunikacyjnych. In: E. CzaplewSkA, \& S. Milewski (Eds.), Diagnoza logopedyczna. Podręcznik akademicki (pp. 15-63). Sopot: Gdańskie Wydaw. Psychologiczne.

Krajna, E. (2002). Doskonalenie artykulacji u dzieci przedszkolnych - wybrane zagadnienia. Logopedia, 31, 27-52.

Krajna, E. (2008). 100-wyrazowy test artykulacyjny. Podręcznik. Gliwice: Wydaw. Komlogo Piotr Gruba.

Krasowicz-Kupis, G. (2004). Rozwój świadomości językowej dziecka. Teoria i praktyka. Lublin: Wydaw. Uniwersytetu Marii Curie-Skłodowskiej.

Lleó, C., \& Prinz, M. (1996). Consonant Clusters in Child Phonology and the Directionality of Syllable Structure Assignmemt. Journal of Child Language, 23, 31-56.

ŁoвACz, P. (1996). Polska fonologia dziecięca. Studia fonetyczo-akustyczne. Warszawa: Wydaw. Energeia.

Łobacz, P. (2005). Prawidłowy rozwój mowy dziecka. In: T. GaŁkowski, E. SzeląG, \& G. JASTRzęвоwsкa (Eds.), Podstawy neurologopedii. Podręcznik akademicki (pp. 231-268). Opole: Wydaw. Uniwersytetu Opolskiego.

MadelsKa, L. (2005). Stownik wariantywności fonetycznej współczesnej polszczyzny. Kraków: Collegium Columbinum. 
Milewski, S. (1998). Nagłosowe grupy spółgłoskowe w tekstach mówionych dzieci w wieku przedszkolnym. In: I. NowAKowsKA-KeMPNA (Ed.), Logopedia jako nauka interdyscyplinarna - teoretyczna i stosowana (pp. 175-211). Katowice: Wydaw. Uniwersytetu Śląskiego.

MiLewsKi, S. (1999). Lingwistyczne i dydaktyczne aspekty analizy fonemowej. Lublin: Wydaw. Uniwersytetu Marii Curie-Skłodowskiej.

Milewski, S. (2001). Śródgłosowe grupy spółgłoskowe w tekstach mówionych dzieci w wieku przedszkolnym. In: S. Grabias (Ed.), Zaburzenia mowy. Vol. 1 (pp. 216-252). Lublin: Wydaw. Uniwersytetu Marii Curie-Skłodowskiej.

Milewski, S. (2005). Grupy spółgłoskowe w języku mówionym dzieci przedszkolnych. Logopeda. Czasopismo internetowe, 1(1), 5-32.

MilewsKi, S. (2017). Grupy spółgłoskowe jako problem logopedyczny. In: S. MilewsKi, K. KaCzorowska-Bray, \& B. KamiŃska (Eds.), Studia logopedyczno-lingwistyczne. Ksiega jubileuszowa z okazji 70-lecia urodzin Profesora Edwarda Łuczyńskiego (pp. 269-294). Gdańsk: Harmonia Universalis.

Porayski-Pomsta, J. (2015). O rozwoju mowy dziecka. Dwa studia. Warszawa: Dom Wydawniczy „Elipsa”.

Przybyla, O. (2013). O kinestezji, praksji oralnej i koordynacji w perspektywie integrującej. In: J. Panasiuk, \& T. Woźniak (Eds.), Język-człowiek-społeczeństwo (pp. 791-811). Lublin: Wydaw. Uniwersytetu Marii Curie-Skłodowskiej.

Przybyla, O. (2015). Motoryczne zdolności koordynacyjne w świetle badań nad mową. In: K. Kaczorowska-Bray, \& S. Milewski (Eds.), Metodologia badańlogopedycznych (pp. 322-363.). Gdańsk: Harmonia Universalis.

RocŁawski, B. (1986a). Poradnik fonetyczny dla nauczycieli. Warszawa: Wydawnictwa Szkolne i Pedagogiczne.

RocŁAWSKI, B. (1986b). Zarys fonologii, fonetyki, fonotaktyki i fonostatystyki współczesnego języka polskiego. Gdańsk: Wydaw. Uczelniane Uniwersytetu Gdańskiego.

SoŁtys-Chmielowicz, A. (1998). Wymowa dzieci przedszkolnych. Lublin: Wydaw. Uniwersytetu Marii Curie-Skłodowskiej.

So£tys-Chmielowicz, A. (2005). Zaburzenia artykulacji. In: T. Ga£kowski, E. Szeląg, \& G. Jastrzęвowska (Eds.), Podstawy neurologopedii. Podręcznik akademicki (pp. 421-474). Opole: Wydaw. Uniwersytetu Opolskiego.

SoŁtys-Chmielowicz, A. (2008). Zaburzenia artykulacji. Teoria i praktyka. Kraków: Impuls.

ŚLEDZIŃsKi, D. (2010). Analiza struktury grup spółgłoskowych w nagłosie oraz w wygłosie wyrazów w języku polskim. Kwartalnik Językoznawczy, 3-4, 61-84.

ŚLEDZIŃSKI, D. (2013). Podział korpusu tekstów na sylaby - analiza polskich grup spółgłoskowych. Kwartalnik Językoznawczy, 3, 48-100.

Wójtowiczowa, J. (1993). Logopedyczny zbiór wyrazów. Warszawa: Wydawnictwa Szkolne i Pedagogiczne.

ZARĘBINA, M. (1965). Kształtowanie się systemu językowego dziecka. Wrocław-Warszawa-Kraków: Zakład Narodowy im. Ossolińskich.

ZaręBina, M. (1994). Język polski w rozwoju jednostki. Gdańsk: Wydaw. Glottispol.

Zgó ŁKowa, H. (2016). Słownictwo dzieci w wieku przedszkolnym w latach 2010-2015. Poznań: Wydaw. Uniwersytetu Adama Mickiewicza.

ZGó£KowA, H., \& BuŁCZYŃsKA, K. (1987). Słownictwo dzieci w wieku przedszkolnym: listy frekwencyjne. Poznań: Wydaw. Uniwersytetu Adama Mickiewicza.

Zydorowicz, P. (2010). Consonant clusters across morpheme boundaries: polish morphonotactic inventory and its acquisition. Poznań Studies in Contemporary Linguistics, 46(4), 565-588. 


\title{
EWA BINKUŃSKA \\ Instytut Logopedii, \\ (D) 0000-0002-3901-7024
}

\section{Tendencje rozwojowe artykulacji głosek szczelinowych i zwarto-szczelinowych w grupach CCV-, -VCC- oraz-VCC w wymowie dzieci trzy-, cztero- oraz pięcioletnich}

\author{
Developmental Tendencies of Articulation of Slit and Compact-slot Sounds \\ in CCV-, -VCC- and -VCC Groups in the Pronunciation of Three-, \\ Four- and Five-year-old Children
}

АвsтRACT: The pronunciation of consonant groups in three-, four-, and five-year-old children is an exponent of the acquired phonological competences. A genuine study has to consider the pronunciation of consonants characteristic of specific early stages of speech development. The element of phonetic neighborhood is also an important aspect, being a decisive feature for the final implementation of a specific consonantal connection. In the speech of preschool children, the implementation of consonant groups (CCV-, -VCC- and -VCC), in addition to the pronunciation consistent with the standard one, includes substitutions, reductions, assimilation, and other phenomena, for instance, epentesis. Moreover, there is the coexistence of several types of pronunciation violations of consonant clusters.

KEY WORDs: pronunciation of consonant groups, pronunciation of preschool children, speech development

\section{Wprowadzenie}

Wymowa grup spółgłoskowych przez dzieci trzy-, cztero- i pięcioletnie stanowi wykładnik osiągniętych kompetencji fonologicznych. Kompetencje te mogą dotyczyć różnych umiejętności, np. realizacji poszczególnych spółgłosek w izolacji, ale także w większych strukturach, np. w sąsiedztwie samogłoskowym, a następnie w zbitkach spółgłoskowych ${ }^{1}$. Jednocześnie realizacje połączeń dwu-, trzy- oraz

${ }^{1}$ Grażyna Krasowicz-Kupis (2004) zwraca w tym kontekście uwagę także na umiejętność intencjonalnego manipulowania fonemami. Do takich umiejętności należy celowe pomijanie określonych dźwięków. 
wieloelementowych kompleksów spółgłoskowych we wspomnianej grupie wiekowej przyjmują postaci zarówno redukcji elementów konsonantycznych, jak i substytucji, upodobnień, bądź nawet uproszczeń polegających na pominięciu danego kompleksu spółgłoskowego wraz z całą sylabą (Barlow, 2003).

Istotnym aspektem badań realizacji grup spółgłoskowych w ontogenezie mowy jest uwzględnienie charakterystycznego dla dzieci w wieku przedszkolnym poziomu kompetencji realizacyjnych, a także norm rozwojowych dotyczących pojawiania się danego elementu konsonantycznego w mowie dziecka. Należy tu wziąć pod uwagę np. palatalną wymowę niektórych głosek, właściwą dla wczesnych etapów rozwoju mowy. W badaniach nad wymową grup spółgłoskowych podstawową rolę odgrywa element sąsiedztwa fonetycznego, który obok opanowanych przez dziecko w danym okresie ontogenezy mowy dźwięków, ma decydujące znaczenie dla ostatecznej realizacji określonego połączenia spółgłoskowego.

W realizacji nagłosowych, śródgłosowych oraz wygłosowych grup spółgłoskowych (CCV-, -VCC- oraz -VCC) w mowie dzieci w wieku przedszkolnym oprócz wymowy zgodnej z normą bądź wspomnianych już substytucji, redukcji czy upodobnień, bądź innych zjawisk, takich jak np. epenteza - zauważa się współwystępowanie kilku objawów naruszenia wymowy zbitek konsonantycznych.

\section{Grupy spółgłoskowe w rozwoju mowy dziecka}

Proces akwizycji kompleksów spółgłoskowych w ontogenezie mowy rozpoczyna się w drugim roku życia - pomiędzy 18. a 24. miesiącem - i poprzedzony jest procesem opanowania sylab CV, CVC, VC (Gwozdiew, 2007, s. 105; Zarębina, 1994, s. 12-18). Sporadycznie grupy spółgłoskowe mogą wystąpić w okresie wcześniejszym. Maria Zarębina (1965, s. 19) zaobserwowała realizację pojedynczych diad konsonantycznych u dzieci w wieku około 14-15. miesiąca życia. Autorka zwraca uwagę na występowanie w ich strukturze spółgłoski zwartej. W publikacji z 1994 roku - Język polski w rozwoju jednostki, Zarębina wspomina o braku występowania grup spółgłoskowych u dwóch chłopców w wieku 1;6 oraz 1;7. Następnie we fragmencie oznaczonym jako tekst zbiorczy dziewcząt i chłopców w wieku do 2;0 autorka zauważa pojawianie się zjawiska uproszczeń grup spółgłoskowych (1994, s. 12-20). Zarębina przedstawia teksty w porządku chronologicznym, można zatem założyć, iż ostatnie ze wspomnianych wypowiedzi należą do grupy dzieci w wieku od $1 ; 8$ do $2 ; 0$.

Pozycją wyrazową, w której jako pierwszej pojawiają się zbitki spółgłoskowe, jest śródgłos wyrazów (Demuth \& Kehoe, 2006, s. 66; Kaczmarek, 1982; Łobacz, 2005, s. 246), inną kolejność pojawiania się zbitek konsonantycznych, np. CCV czy CVCC, uważa się za nietypową lub wręcz towarzyszącą zakłóceniom bądź 
zaburzeniom związanym z procesem nabywania kompetencji komunikacyjnych (Zydorowicz, 2010, s. 572). Jak wspomniano, proces przyswajania wymowy grup konsonantycznych rozpoczyna się $\mathrm{w}$ drugim roku życia dziecka, a w ich strukturze zwykle zauważa się występowanie spółgłoski zwartej, nosowej lub płynnej (Łobacz, 2005, s. 244; Zarębina, 1965, s. 19-33). Jednym z procesów dominujących, charakterystycznych dla wymowy grup spółgłoskowych u dzieci w wieku przedszkolnym są uproszczenia towarzyszące realizacji zbitek konsonantycznych. Piotr Łobacz z kolei zauważa, iż około siódmego roku życia opuszczenia towarzyszące wymowie grup spółgłoskowych należą do rzadkości (Kielar-Turska, 2012, s. 45; Łobacz, 2005, s. 260).

\section{Podstawy metodologii badań}

Celem prezentowanych badań jest wskazanie zmian realizacyjnych występujących w wymowie grup spółgłoskowych zawierających głoski szczelinowe i zwarto-szczelinowe oraz tendencji rozwojowych właściwych artykulacji dzieci w wieku przedszkolnym - pomiędzy 37. a 72. miesiącem życia. Uzasadnieniem podjętych badań jest niedosyt opracowań dotyczących przyswajania realizacji grup spółgłoskowych w ontogenezie mowy. Szczegółowa analiza tego zjawiska może stanowić podstawę określenia norm dotyczących akwizycji połączeń konsonantycznych, co byłoby istotne zarówno w aspekcie logopedycznym, jak i tworzenia programów terapii zaburzeń mowy.

Badania odbyły się w pięciu trójmiejskich placówkach oświatowych i trwały dziewięć miesięcy - od października 2016 roku do czerwca 2017 roku. Populację badawczą stanowiło 210 dzieci. Była to stała grupa nagrywana raz w miesiącu. Materiałem stanowiącym podstawę badań były nagrania obejmujące cztery próby językowe. Pierwszą było nazywanie obrazków znajdujących się w opracowanym arkuszu zawierającym rysunki bądź zdjęcia desygnatów, których nazwy posiadały dwu-, trzy- bądź więcej elementowe grupy spółgłoskowe w nagłosie, śródgłosie oraz wygłosie wyrazów. Ze względu na brak narzędzia diagnostycznego pozwalającego na badanie realizacji grup spółgłoskowych (Binkuńska, 2017; Kania, 2001, s. 187; Krajna, 2008, s. 15; Milewski, 2017, s. 272, Przybyla 2013, s. 802-809; 2015, s. 355-362), w celu przeprowadzenia badania realizacji zbitek konsonantycznych, opracowany został kwestionariusz obrazkowy. Zawarty w nim materiał wyrazowy zgromadzony został na podstawie: Słownictwa dzieci w wieku przedszkolnym: listy frekwencyjne Haliny Zgółkowej i Katarzyny Bułczyńskiej (1987)²; Słownika

2 Jednocześnie podkreślić należy, iż w 2016 roku pojawiło się nowsze opracowanie, zatytułowane Słownictwo dzieci w wieku przedszkolnym w latach 2010-2015 autorstwa Haliny Zgółkowej 
wariantywności fonetycznej współczesnej polszczyzny Liliany Madelskiej (2005); Logopedycznego zbioru wyrazów Janiny Wójtowiczowej (1993).

Drugą próbą było powtarzanie wyrazów. W tej części badania wykorzystano materiał leksykalny, który znalazł się we wspomnianym kwestionariuszu. Kolejną część badania stanowiło nagranie rozmowy rówieśników danej grupy przedszkolnej, prowadzonej w parach bądź w zespołach trzyosobowych. Ostatnią próbę stanowiła rozmowa $\mathrm{z}$ osobą prowadzącą badania. Początkowo była to rozmowa kierowana, a pretekstem był przygotowany wcześniej temat związany z pobytem dziecka w przedszkolu, zabawą, porami roku, świętami itd. Jeśli dziecko-rozmówca zmieniło temat rozmowy, prowadzący badanie odstępował od pierwotnej tematyki i pozwalał na tę zmianę.

W niniejszym opracowaniu wzięto pod uwagę wymowę grup spółgłoskowych, w skład których wchodziły przynajmniej dwie głoski szczelinowe, zwarto-szczelinowe bądź jedne i drugie.

\section{Fonologiczne podstawy opracowania danych}

W celu opracowania wyników badań przeprowadzono transkrypcję dziecięcych tekstów. Przyjęto system fonologiczny zaproponowany przez Bronisława Rocławskiego (1986a, s. 23-24; 1986b, s. 85-86), zawierający następujące fonemy spółgłoskowe: /p, b, t, d, k, g, c, z, ć, ź, č, ̌̌, f, v, s, z, ś, ź, š, ž, x, m, n, ń, l, r, u, il. Podstawowym kryterium analizy było wyróżnienie konsonantów szczelinowych: /f, v, s, z, ś, ź, š, ž, x/; oraz zwarto-szczelinowych: /c, 3, ć, ’́, č, ̌̌/ (Dyszak, Laskowska, \& Święcicka, 1997, s. 56-61; Rocławski, 1986a, s. 23-24).

Normy związane $\mathrm{z}$ wiekiem dzieci, $\mathrm{w}$ jakim opanowana zostaje realizacja określonych głosek szczelinowych i zwarto-szczelinowych, przyjęto na podstawie opracowania Małgorzaty Bryndal (2015, s. 100-101). Przyjmuje ona kryterium, zgodnie z którym o zakończeniu procesu akwizycji głosek świadczy ich występowanie w wartości powyżej 90\%. Uwzględniając procesy przyswajania realizacji poszczególnych głosek szczelinowych i zwarto-szczelinowych w ontogenezie mowy, założono, iż głoski [f, v] przyswojone są przez dzieci należące do wszystkich badanych grup wiekowych - przez trzy-, cztero- i pięciolatki (por. Dołęga, 2003; Łobacz, 1996, s. 143).

Procent przyswojenia spółgłoski [ś] występuje w populacji dzieci trzyletnich na poziomie $91 \%$ i jest on taki sam, jak w przypadku głoski [v]. Na tej podstawie można zatem założyć, iż w populacji trzylatków wymowa wszystkich trzech

(2016). Jednak nie zostało ono uwzględnione, ponieważ zarówno przygotowanie kwestionariusza obrazkowego, jak i rozpoczęcie badań miało miejsce jeszcze przed ukazaniem się niniejszej pozycji. 
wspomnianych powyżej głosek została przyswojona. Jednak proces przyswajania pozostałych spółgłosek środkowo-językowych - szczelinowej, dźwięcznej [ź] oraz zwarto-szczelinowych [ć, j́] - nie został jeszcze ukończony (por. Kania, 2001, s. 85; Sołtys-Chmielowicz, 1998). Sytuacja ta zwraca uwagę przede wszystkim $\mathrm{z}$ tego względu, iż zgodnie z danymi prezentowanymi przez Bryndal proces akwizycji bezdźwięcznej, szczelinowej, spółgłoski środkowo-językowej [ś] w populacji dzieci w wieku trzech lat został już ukończony. Akwizycja pozostałych spółgłosek środkowo-językowych [ź, ć, j̉] zostaje ukończona w kolejnym roku życia.

Dzieci czteroletnie stanowią również grupę, w której rozwojowo uznaje się za ukończone przyswajanie kolejnej spółgłoski - szczelinowej, bezdźwięcznej, przedniojęzykowo-zębowej - [s], jednak - podobnie jak miało to miejsce w przypadku głosek środkowo-językowych - także realizacja pozostałych dźwięków przedniojęzykowo-zębowych (tzw. szeregu syczącego) - spółgłoski szczelinowej i zwarto-szczelinowych, przedniojęzykowo-zębowych $[z, c, 3]$ nie jest jeszcze opanowana, można jedynie mówić o rozpoczętym procesie przyswajania ich normatywnej realizacji, natomiast ich akwizycja dobiega końca dopiero u dzieci, które ukończyły piąty rok życia. Akwizycja pozostałych głosek szczelinowych i zwarto-szczelinowych - dziąsłowych - rozpoczyna się we wspomnianej grupie wiekowej, natomiast dobiega końca w grupie sześciolatków (Bryndal, 2015, s. 100; Krajna, 2002, s. 35).

Proces przyswajania poszczególnych głosek ma charakter postępowy i związany jest $\mathrm{z}$ dojrzewaniem umiejętności komunikacyjnych, motorycznych oraz słuchowych (Bee, 2004, s. 200-203; Porayski-Pomsta, 2015, s. 139, 152). Jednak granice wiekowe są w tym wypadku trudne do jednoznacznego określenia (por. Czaplewska, 2012, s. 91). Jedną z cech wspólnych dla wspomnianych głosek, biorąc pod uwagę wyniki Bryndal, jest szybsze opanowanie w przypadku omawianych głosek środkowo-językowych, językowo-zębowych oraz dziąsłowych, trzech głosek szczelinowych, bezdźwięcznych - [ś], [s] i [š] - a dopiero później pozostałych głosek danego szeregu, a zatem najpierw opanowana zostaje spółgłoska [ś], potem [ź, ć, ’́], przyswojenie realizacji [s] poprzedza wymowę [z, c, 3], a akwizycja [š] następuje wcześniej niż [ž, č, ̌̌]].

Z kolei ostatnią, najtrudniejszą głoską w przypadku środkowo-językowych i przedniojęzykowo-zębowych okazało się przyswajanie głosek zwarto-szczelinowych dźwięcznych [3́] oraz [3], natomiast w przypadku spółgłosek dziąsłowych najtrudniejszą w ontogenezie okazała się głoska dźwięczna, szczelinowa [ž]. Pewnego rodzaju konsekwencję można natomiast zaobserwować w przypadku przyswajania głosek zwarto-szczelinowych, bezdźwięcznych [ć, c, č]. Proces ich przyswajania przebiega równocześnie z przyswajaniem spółgłoski szczelinowej bezdźwięcznej, akwizycja kończy się jednak zwykle wtedy, gdy nastąpi już strukturalizacja wymowy pierwszej ze wspomnianych głosek (por. M. Bryndal, 2015, s. 101). 


\section{Proces akwizycji grup spółgłoskowych na tle przyswajania realizacji konsonantów}

Przedstawione powyżej dane dotyczące zakończenia akwizycji określonych spółgłosek nie odnoszą się jednak do ich realizacji w grupach spółgłoskowych (Milewski, 1999, s. 136-140; 2005, s. 6). Stanisław Milewski stwierdza, iż naruszenie struktury połączeń konsonantycznych towarzyszy wymowie dzieci w szóstym, a nawet jeszcze w siódmym roku życia - a zatem wtedy, gdy spółgłoski szczelinowe i zwarto-szczelinowe są już realizowane zgodnie z normą wymawianiową (por. Czaplewska, 2012, s. 91). Zatem w realizacji grup spółgłoskowych, już po zakończeniu okresu, w którym następuje przyswajanie wymowy poszczególnych głosek, nadal obserwuje się naruszenia występujące np. w postaci redukcji.

Znaczne różnice dotyczące przyswojenia wymowy spółgłosek występujące w zbitkach konsonantycznych na tle ich realizacji w sąsiedztwie samogłoskowym świadczą o tym, iż to właśnie sąsiedztwo spółgłoskowe stanowi specyficzne uwarunkowanie decydujące o pojawianiu się w mowie dzieci modyfikacji, takich jak m.in.: uproszczenia, upodobnienia, substytucje, epentezy itd. Przykład tego rodzaju zjawiska stanowi akwizycja głosek [f], [v], [s], [z]. Wymowa wspomnianych spółgłosek zostaje opanowana dość wcześnie. Głoski [f] i [v] można uznać za przyswojone już w populacji trzylatków. Akwizycja spółgłoski [f] w sąsiedztwie samogłoski wynosi 94\%, z kolei [v] - 91\%. Jednak w grupach spółgłoskowych, biorąc pod uwagę wymowę dzieci trzyletnich, głoska [f] została przyswojona w przypadku $66 \%$ realizacji, natomiast $[\mathrm{v}]-50 \%$. Zatem, gdy porówna się realizację tych spółgłosek w połączeniach konsonantycznych oraz ich wymowę w sąsiedztwie samogłoski w poszczególnych grupach wiekowych, różnice są znaczne.

Również [s] i [z] charakteryzuje dość wysoki wskaźnik akwizycji, gdy głoski występują poza grupami spółgłoskowymi. Zbitka spółgłoskowa, szczególnie jeśli w jej skład wchodzą głoski o tych samych cechach artykulacyjnych, np. takim samym sposobie artykulacji (w tym wypadku spółgłoski szczelinowe, ale także np. dźwięczne), stanowią kontekst sprzyjający występowaniu w ramach takich grup zjawisk fonetycznych, np. uproszczeń. Stąd częsta w populacji trzylatków wymowa: /zul/ zamiast /vzul/ czy /vzur/ 'wzór'; /sxut/ zamiast /fsxut/ 'wschód'. Największe różnice dotyczące przyswojenia poszczególnych spółgłosek pojawiających się w sąsiedztwie samogłoskowym oraz w zbitce spółgłoskowej występują właśnie w populacji dzieci trzyletnich i wynoszą nawet $41 \%$ w przypadku spółgłoski [v], 31\% gdy weźmie się pod uwagę głoskę [ś], 28\% zaś w wymowie [f]. 


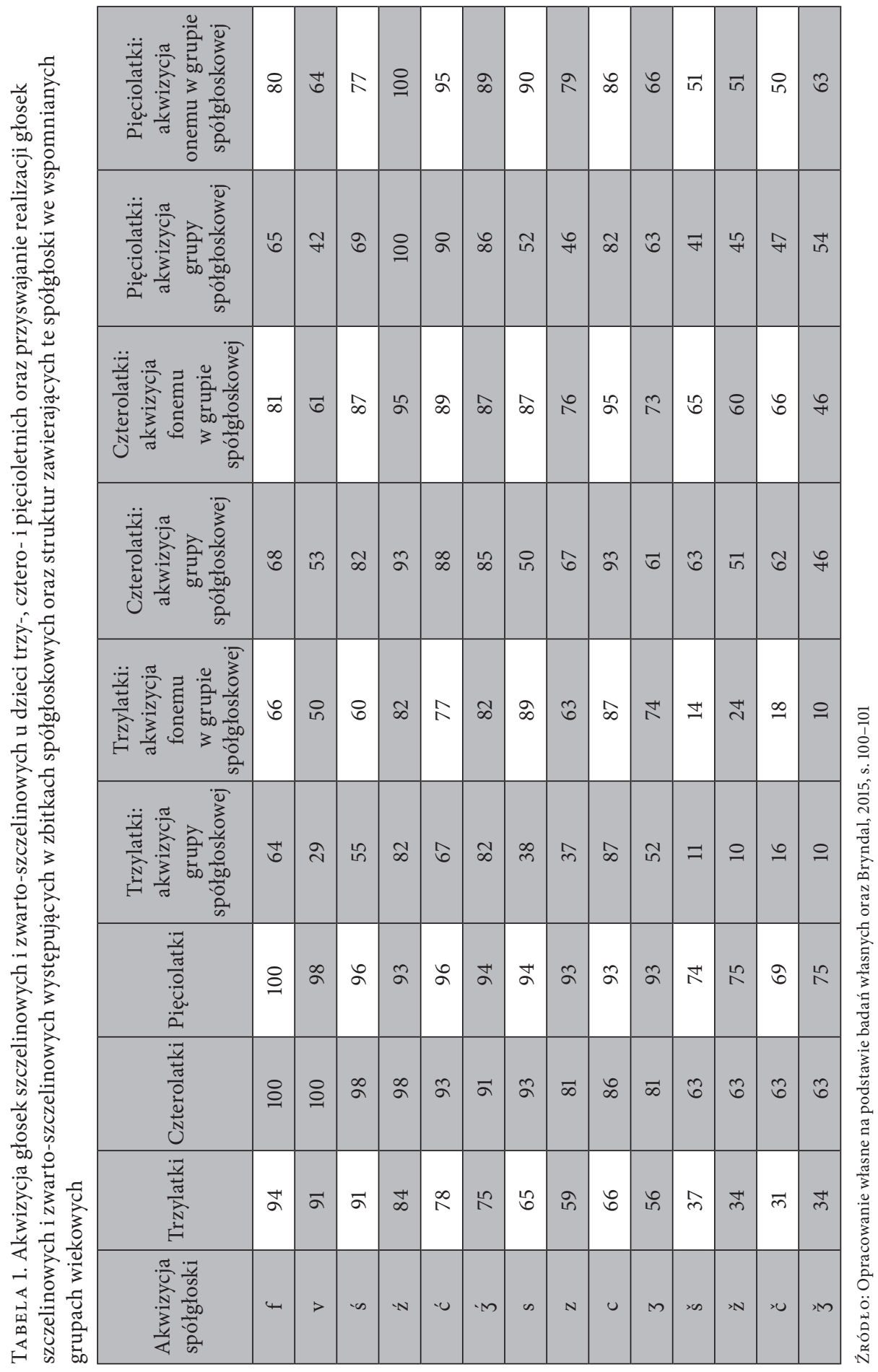




\section{Grupy konsonantyczne zawierające spółgłoski szczelinowe oraz zwarto-szczelinowe w realizacji dzieci trzyletnich}

Jednym ze zjawisk, jakie najczęściej można zaobserwować w realizacji nagłosowych grup spółgłoskowych zawierających głoski szczelinowe i zwarto-szczelinowe w grupie dzieci trzyletnich, jest redukcja dźwięków wchodzących w skład zbitek konsonantycznych. Oto przykłady tego rodzaju realizacji: /zul/ 'wzór', /sufka/ 'wsówka', /zońi/ 'dzwoni', /zonki/ 'dzwonki', /gvoźe/ 'gwoźdźe', /koś/ 'kość'. Przykładem uproszczenia występującego w obrębie trójelementowej grupy spółgłoskowej może być połączenie: /śfi-/. Najczęściej grupa spółgłoskowa /śfi-/ redukowana była do pojedynczego fonemu: /ś-/ - /śećńik/, /śeca/; /ć-/ - /ćeca/, ale występowała również w postaci diady /fí-/ - /fiećńik/, /fieca/, /fiećki/. Pojawiła się także wymowa z przedniojęzykowo-zębową głoską [s-] - /sieca/ (Milewski, 1998, s. 187).

Uproszczenia zbitek spółgłoskowych dotyczyły licznej grupy wyrazów. Oprócz wspomnianych jednostek, takich jak np.: 'świeca' - wymawiana jako /śieca/, 'świecznik' - /śiećńik/, zjawisko redukcji często występowało również w następujących leksemach: 'wzburzone' realizowne jako /buzone/, /zbuzone/; 'wzbija się' - /zbiia śę/; 'wejśćie' - /veiće/. Redukcje połączeń konsonantycznych wystąpiły też w nagłosowych grupach spółgłoskowych, takich jak: /3v-/, /亏́g-/, /čf-/, /žv-/, /vž-/, /vz-/, /fs-/, /xš-/, /vzb-/, /vzm-/, /fsp-/.

W grupie dzieci trzyletnich w przypadku wielu jednostek leksykalnych uproszczeniu zbitek spółgłoskowych towarzyszyła substytucja. W większości realizacji głoski [š, ž, ̌́, ̌̌], a często również [s, z, c, 3], zamieniane były na pojawiające się wcześniej w ontogenezie mowy spółgłoski środkowo-językowe [ś, ź, ć, ̧́] (por. Sołtys-Chmielowicz, 2005, s. 459). Na przykład występująca w analizowanym materiale wyrazowym zbitka konsonantyczna /šč-/, w której skład wchodzą głoski przedniojęzykowo-dziąsłowe, szczelinowa oraz zwarto-szczelinowa, realizowana była jako [ć], rzadziej [c], sporadycznie natomiast [č]. Przykładami są w tym przypadku następujące wyrazy: 'szczypiorek' - /ćipiolek/, /cypiolek/, (rzadko /čypiolek/); 'szczeniak' - /ceńak/; 'szczupak' - /cupak/; 'szczur' - /cul/. Z kolei przykładem współwystępowania uproszczenia wraz z substytucją w obrębie nagłosowej triady spółgłoskowej jest sąsiedztwo np. [pšč-], które ulegając redukcji, realizowane było jako [c-] bądź [pc-]. Dzieci trzyletnie wymawiały zatem w tym wypadku wyrazy: /couna/ lub /pcouna/.

Realizacja licznej grupy wyrazów zawierała substytucje obejmujące głoski wchodzące w skład połączeń konsonantycznych (Sołtys-Chmielowicz, 2008, s. 137-139). Najczęściej zamieniane były fonemy /š, ž, č, ̌̌/ oraz /s, z, c, z/, ale zdarzały się również substytucje /ś, ź, ć, źl. Przykładem tego rodzaju realizacji jest zarówno wspomniana wcześniej wymowa wyrazów 'szczeniak' jako /sceńak/, 'szczupak' jako /scupak/ czy 'oszczędza' jako /oscenza/, ale również /sfinka/ 'śfinka', /zvik/ 'dźwik'. 
Kolejnym zjawiskiem, jakie występowało w wymowie dzieci trzyletnich, była epenteza polegająca na rozszerzeniu grupy spółgłoskowej o głoskę szczelinową bądź zwarto-szczelinową, np.: /scs-/ w wyrazie /scsypiolek/, /zvz-/ - /zvzul/, /vzv-/ - /vzvil/, /sps/ - /spsouna/, /ssf-/ - /ssfonki/3. . Tego typu realizacje stanowią przykład pojawiania się w wymowie trzylatków nowych grup, które nie występują w języku polskim (Milewski, 2005, s. 17).

Wymowie dzieci trzyletnich w przypadku zbitek dźwięcznych spółgłosek szczelinowych /vz-/ najczęściej towarzyszyła redukcja, pojawiała się również wspomniana powyżej epenteza, zdarzało się także rozbicie grupy spółgłoskowej poprzez dodanie elementu wokalicznego, jak np. w wyrazie /z(y)sul/ 'wzór', oraz modyfikacja w zakresie kolejności wymawianych konsonantów: /vz-/ /zvul/; także ich dźwięczności i miejsca artykulacji /s-/, /syzul/; czy w wyrażeniu 'wzbudza podziw' /zybuza/, w którym w przypadku triady /vzb-/ oprócz redukcji pierwszego elementu wystąpiła epenteza - element wokaliczny /y/ rozbił sąsiadujące ze sobą spółgłoski $[\mathrm{z}]$ oraz [b]. W wymowie dzieci trzyletnich epenteza polegająca na użyciu zarówno dodatkowej spółgłoski, jak i samogłoski nie należała do zjawisk często występujących. Ten rodzaj zjawiska językowego w większym zakresie można było zaobserwować $\mathrm{w}$ realizacjach czterolatków.

W nielicznej grupie wyrazów pojawiło się również uproszczenie nagłosu. Wystąpiło ono w postaci braku realizacji całej grupy spółgłoskowej, np. /vž-/, w jednostce leksykalnej 'wrzeciono' realizowanej jako /ećona/ - w tym przypad$\mathrm{ku}$ nastąpiła również zmiana formy fleksyjnej lub redukcji ulegała cała sylaba, np. /ćono/.

\section{Grupy konsonantyczne zawierające spółgłoski szczelinowe oraz zwarto-szczelinowe w realizacji dzieci czteroletnich}

W grupie dzieci czteroletnich, w porównaniu z populacją trzylatków, zjawisko uproszczeń grup spółgłoskowych zawierających głoski szczelinowe oraz zwarto-szczelinowe występuje rzadziej. ${ }^{4}$. Wśród czterolatków redukcja połączeń konsonantycznych, które zawierają omawiane spółgłoski, dotyczy przede wszystkim takich jednostek leksykalnych jak: 'wrzos' realizowanych jako /žos/, 'wspina się' jako /spina śę/, 'wzburzone' jako /zbuzone/ lub /buzone/5, 'wsuwka' jako/sufka/, 'wschód' jako /sxut/, 'dzwonki' jako /vonki/, 'szczupak' jako/šupak/, 'pszczoła'

${ }^{3}$ Zarówno Piotra Łobacz (2005, s. 248), jak i Maria Zarębina (1965, s. 91) zauważają, iż spółgłoska [s] pojawia się w grupach spółgłoskowych dość wcześnie.

${ }^{4}$ Podobna tendencja utrzymuje się w grupie pięciolatków.

${ }^{5}$ W grupie czterolatków wielokrotnie występowała również poprawna realizacja /vzbužone/. 
jako /pčouna/, /pšouna/ lub /čouna/, 'dżdżownica' jako /క̌ovńica/, 'wejście’ jako /eiće/ oraz 'deszcz' jako/deš/. Oprócz redukcji występującej w obrębie grupy spółgłoskowej zdarzają się również redukcje sylaby zawierającej zbitkę spółgłoskową, np. wymowa wyrazu 'szczypiorek' jako /polek/ lub /spiolek/.

Dominującym w grupie dzieci czteroletnich zjawiskiem jest substytucja. Dotyczy ona również spółgłosek wchodzących w skład zbitek konsonantycznych. Przykładami ilustrującymi proces mogą być wyrazy: /sceńak/ 'szczeniak', /zvil/ 'żwir', /scypiolek/, /śćipiolek/ 'szczypiorek', /pscouna/ 'pszczoła', /vzescy/ 'wrzeszczy', /des/ 'deszcz' (Milewski, 1998, s. 184-185; 2001, s. 232-233). Sporadycznie w tej grupie wiekowej pojawia się substytucja będąca jednocześnie hiperpoprawną realizacją głosek szczelinowych bądź zwarto-szczelinowych, np. w leksemie 'dźwik' wymawianym jako /క̌vik/. Współwystępowanie zjawiska substytucji oraz redukcji dotyczy przede wszystkim połączenia spółgłosek [šč-] zarówno w obrębie diad, jak i triad konsonantycznych /śul/ 'szczur', /osenza/ 'oszczędza', a także 'pszczoła' /psoua/.

Pojawiająca się w wymowie dzieci czteroletnich epenteza, biorąc pod uwagę grupy spółgłoskowe zawierające głoski szczelinowe oraz zwarto-szczelinowe, najczęściej występowała w nagłosie i polegała na dodaniu elementu konsonantycznego. Sytuacja taka miała miejsce np. w wyrazie 'pszczoła' realizowanym jako /fpčouna/ bądź 'wzór' jako /sscul/. W niektórych wyrazach - podobnie jak miało to miejsce w wymowie dzieci trzyletnich - dodanym dźwiękiem była samogłoska. W wyniku tego zjawiska dochodziło do rozbicia grupy spółgłoskowej. Taką sytuację spotyka się w wyrazie /tefurka/ 'czwórka' - w tym przypadku dodatkowo wystąpiła substytucja głoski [č] zamienionej na spółgłoskę [t].

Kolejnym sposobem naruszenia realizacji grup spółgłoskowych jest upodobnienie. Szczególną trudność - podobnie jak w przypadku trzylatków - sprawiała dzieciom czteroletnim wymowa zbitki konsonantycznej, w której skład wchodziły głoski szczelinowa i zwarto-szczelinowa, dziąsłowa: [šč-]. Sytuacja ta dotyczyła wyrazów: 'pszczoła' realizowanego jako /ssounaa/, 'szczypiorek - /ssypiolek/, 'szczupak' - /sśupak/ lub /skupak/.

\section{Grupy konsonantyczne zawierające spółgłoski szczelinowe oraz zwarto-szczelinowe w realizacji dzieci pięcioletnich}

Występujący w grupie dzieci pięcioletnich proces redukcji połączeń konsonantycznych dotyczył określonych wyrazów. Były to np. takie jednostki leksykalne jak: 'dżdżownica' realizowane często jako /క̌ovńica/, 'wzbija się' jako /zbiia śę/, 'wzmacniacz' jako/zmacńač/, 'wspina się’ jako /spina śę/ lub /pina śę/, 'wsuwka' jako /sufka/, 'wrzeciono’ wymawiane jako/žećono/, 'wschód’ jako /sxut/, ‘dzwo- 
nek' /vonek/; 'szczypiorek' /čypiorek/; 'pszczoła' jako /pčouna/, /pšouna/ lub /čouna/, 'wzburzone' jako /zbužone/. Najczęściej pomijanymi spółgłoskami były szczelinowe, wargowo-zębowe [v] oraz [f].

W wymowie dzieci pięcioletnich nadal obserwuje się zjawisko substytucji. Biorąc pod uwagę realizacje analizowanych w tym opracowaniu głosek szczelinowych oraz zwarto-szczelinowych, dotyczy ono przede wszystkim zamiany spółgłosek [̌̌, ž, č, ̌̌] i występuje w licznej grupie wyrazów, a jako przykład tego procesu językowego można przytoczyć następujące jednostki leksykalne: 'oszczędza' /oscenza/, 'wrzeszczy' /vzescy/, 'owca' /ofsa/, 'szczypiorek' /scypiorek/, 'dźwik' /dvik/, 'żwir' /zvil/, 'szczupak'/sčupak/ lub częściej /scupak/, a także 'dzwoni' /zunońi/. W pewnych wyrazach zamiana spółgłosek przyjmuje charakter hiperpoprawności. Dzieje się tak w wyrazach: 'dzwonek' wymawianym jako /žvonek/ oraz 'zburzone' realizowanym jako /žbužone/. W tym drugim przypadku hiperpoprawność jest najprawdopodobniej skutkiem upodobnienia, polegającego na zmianie miejsca artykulacji z przedniojęzykowo-zębowego charakterystycznego dla głoski [z] na przedniojęzykowo-dziąsłowe, jakie charakterystyczne jest dla występującej w śródgłosie spółgłoski [ž].

Współwystępowanie procesów językowych, takich jak substytucja i redukcja, dotyczy w tej populacji już niewielkiej grupy wyrazów. Są to: 'wrzos' wymawiany jako /zos/, 'wrzeciono' jako/zećono/, 'pszczoła'/psouna/, 'szczupak'/cupak/. Procesy jednoczesnego występowania substytucji oraz redukcji zaobserwowano w grupach spółgłoskowych zbudowanych $\mathrm{z}$ dwóch głosek o tym samym sposobie artykulacji [vž-] oraz posiadających tę samą cechę dźwięczności; a także w grupie [šč-], w której również cechą wspólną jest bezdźwięczna realizacja, spółgłoski te mają też to samo dziąsłowe miejsce realizacji, natomiast jedna $\mathrm{z}$ nich jest szczelinowa, druga zwarto-szczelinowa.

Pozostałe rzadziej występujące zjawiska to redukcja oraz hiperpoprawność w realizacji wyrazu 'kość' jako /koš/; pięciokrotnie pojawiająca się w zebranym materiale zamiana miejsca artykulacji z głoski wargowo-zębowej na wargową w wyrazach 'wrzos' /bžos/ - wyraz został w ten sposób zrealizowany trzykrotnie; oraz /bžećono/ - dwukrotnie. Do nietypowych substytucji można również zaliczyć wymowę wyrazu 'szczupak' jako /skupak/. Specyficzna jest w tym przypadku zmiana miejsca artykulacji z realizacji dziąsłowej charakterystycznej dla głoski [č] na tylnojęzykową [k] - niemniej powstała w wyniku tego procesu grupa spółgłoskowa /sk/ należy do najczęściej występujących w języku polskim (Śledziński, 2010, s. 69). Drugim przykładem jest trzykrotna wymowa leksemu 'dzwonki' jako /zvonki/ ze zmianą głoski zwarto-szczelinowej na szczelinową. 


\section{Analiza porównawcza ilościowa obejmująca realizację głosek szczelinowych i zwarto-szczelinowych w grupie dzieci trzy-, cztero- i pięcioletnich}

W analizowanej grupie wiekowej redukcja należała do dominujących zjawisk, jakie pojawiły się w nagłosie wyrazów. Wystąpiła ona w przypadku 43\% leksemów. Substytucje pojawiające się w niezredukowanej grupie spółgłoskowej dotyczyły $21 \%$ realizacji, natomiast redukcję współwystępującą wraz z substytucją zaobserwowano w 18\% wyrazów. Proporcje te zmieniają się jednak w śródgłosie oraz wygłosie wyrazów, gdzie dominującym procesem stają się substytucje spółgłosek.

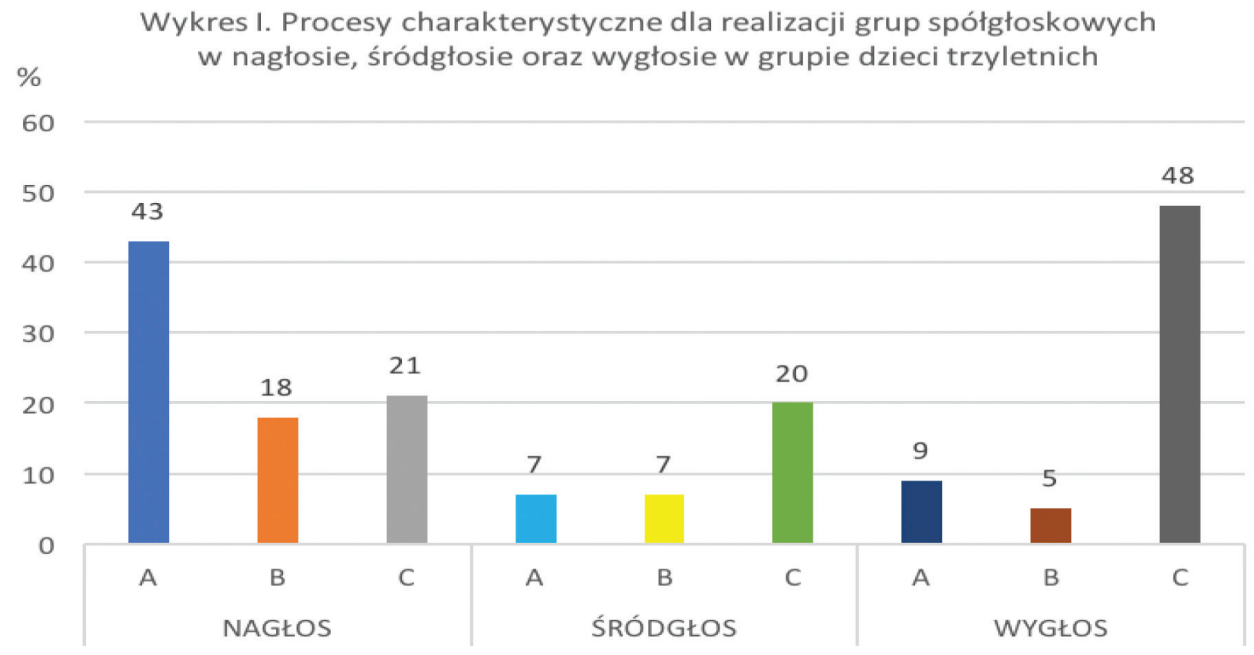

Wy KRES 1. Procesy charakterystyczne dla realizacji grup spółgłoskowych zawierających głoski szczelinowe i zwarto-szczelinowe w nagłosie, śródgłosie oraz wygłosie w grupie dzieci trzyletnich A - redukcje występujące w obrębie grupy spółgłosek szczelinowych i/bądź zwarto-szczelinowych

B - współwystępowanie substytucji oraz redukcji głosek szczelinowych i/bądź zwarto-szczelinowych w grupie spółgłoskowej

C - substytucje głosek występujące w obrębie realizowanej grupy spółgłosek szczelinowych i/bądź zwarto-szczelinowych

ŹróDŁo: Opracowanie własne.

W wymowie grup spółgłoskowych w populacji dzieci czteroletnich zauważa się znaczny spadek procentowy wyrazów, w których występujące w nagłosie grupy spółgłoskowe ulegają redukcji. Dominującym zjawiskiem staje się natomiast substytucja głosek wchodzących w skład połączeń konsonantycznych. Proces jako dominujący dotyczy zarówno pozycji nagłosu, śródgłosu, jak i wygłosu (wykres 2). 


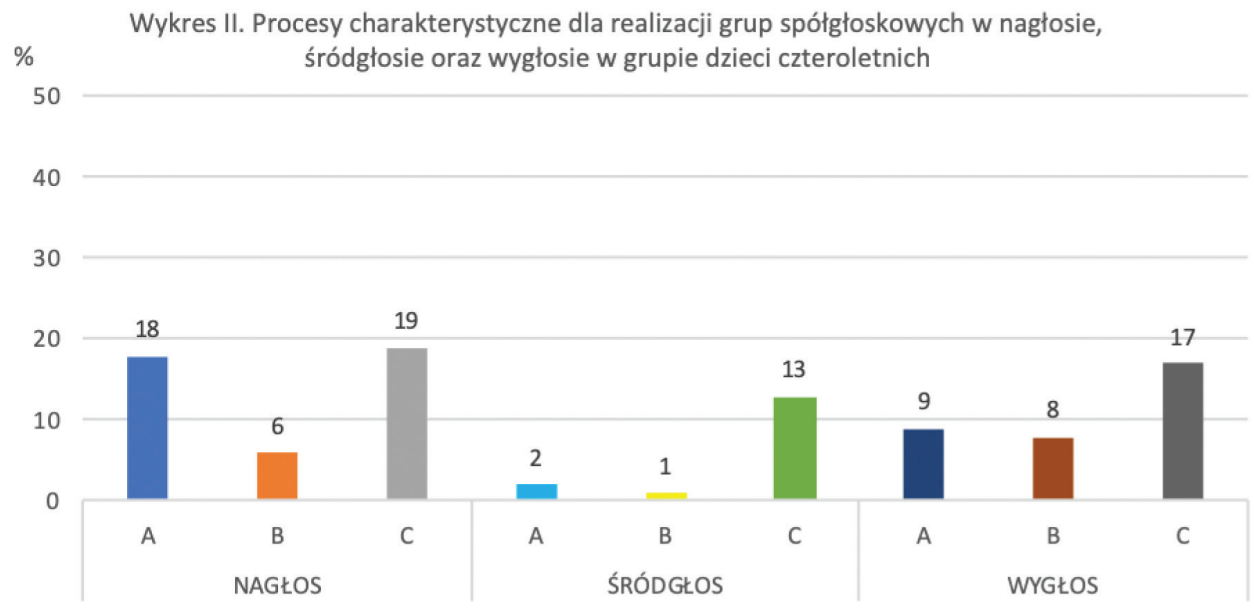

WYKRES 2. Procesy charakterystyczne dla realizacji grup spółgłoskowych zawierających głoski szczelinowe i zwarto-szczelinowe w nagłosie, śródgłosie oraz wygłosie w grupie dzieci czteroletnich A - redukcje występujące w obrębie grupy spółgłosek szczelinowych i/bądź zwarto-szczelinowych B - współwystępowanie substytucji oraz redukcji głosek szczelinowych i/bądź zwarto-szczelinowych w grupie spółgłoskowej

C - substytucje głosek występujące w obrębie realizowanej grupy spółgłosek szczelinowych i/bądź zwarto-szczelinowych

ŹRóD£o: Opracowanie własne.

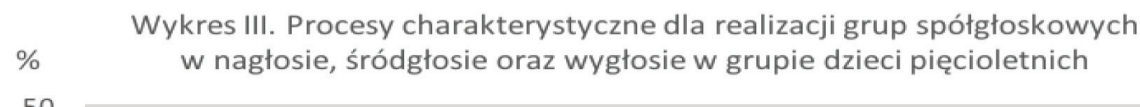

50

40

30

20

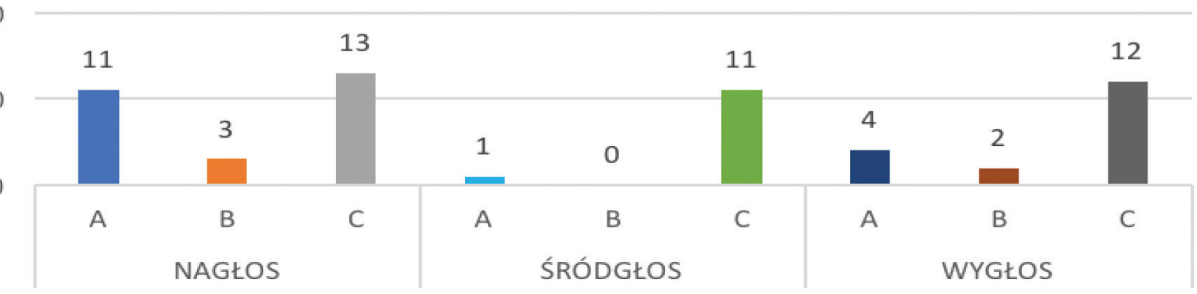

Wy kRES 3. Procesy charakterystyczne dla realizacji grup spółgłoskowych zawierających głoski szczelinowe i zwarto-szczelinowe w nagłosie, śródgłosie oraz wygłosie w grupie dzieci pięcioletnich A - redukcje występujące w obrębie grupy spółgłosek szczelinowych i/bądź zwarto-szczelinowych B - współwystępowanie substytucji oraz redukcji głosek szczelinowych i/bądź zwarto-szczelinowych w grupie spółgłoskowej

C - substytucje głosek występujące w obrębie realizowanej grupy spółgłosek szczelinowych i/bądź zwarto-szczelinowych

ŹróD£o: Opracowanie własne. 
W populacji dzieci pięcioletnich, obok coraz rzadziej występującej nienormatywnej realizacji wyrazów zawierających w swojej strukturze grupy spółgłoskowe, obserwuje się zbliżony wynik substytucji we wszystkich pozycjach w jednostce leksykalnej. W nagłosie zjawisko zamiany głosek wyniosło 13\% realizacji leksemów, w śródgłosie - 11\%, w wygłosie natomiast - 12\%. Częstotliwość występowania uproszczenia grup spółgłoskowych oraz substytucji pojawiającej się w nagłosie wyrazów osiągnęła zbliżoną wartość. Zatem pierwszy z procesów miał miejsce w przypadku 11\% realizacji, drugi - jak wspomniano wcześniej w 13\% (wykres 3).

\section{Analiza porównawcza jakościowa realizacji grup spółgłoskowych zawierających głoski szczelinowe oraz zwarto-szczelinowe w wymowie dzieci trzy-, cztero- oraz pięcioletnich}

Z pewnością najwięcej poprawnych realizacji grup spółgłoskowych zaobserwowano w grupie dzieci pięcioletnich. Jednak uwzględniając aspekt jakościowy zmian, jakie wystąpiły w wymowie połączeń konsonantycznych, w grupie czterolatków zaskakuje różnorodność realizacji tej samej grupy spółgłoskowej, np. zbitka /śfi/ w wyrazie 'świeczki' na 21 realizacji 8 razy wymówiona została zgodnie $\mathrm{z}$ normą /śfiečki/, natomiast w pozostałych 13 realizacjach pojawiały się następujące sposoby jej naruszeń: /ś/ - /śecki/, /śí-/ - /śsiecki/, /śíečki/, /fí/ - /fiecki/, /sfi-/ - /sfiecki/ (por. Milewski, 2005, s. 16). W wyrazie 'chrząszcz' nagłosowa grupa spółgłoskowa /xš-/ była wymawiana jako /xš-/, /kš-/, /xs-/, /kš-/, /s-/, /ś-/; z kolei zbitka /šč-/ występująca w wygłosie realizowana była jako /-šč/ oraz /-sc/, /-šč/, /-̌̌l, /-c/, /-nč/, /-ńć/; w ten sposób w wymowie dzieci czteroletnich powstały następujące wyrazy: /sąsc/, /kšąšč/, /xsąsc/, /xšąč /, /xsąc/, /kšonč/, /xšąč/, /śońć/ (Milewski, 1998, s. 182). Grupa spółgłoskowa /క̌žš-/ wystę-

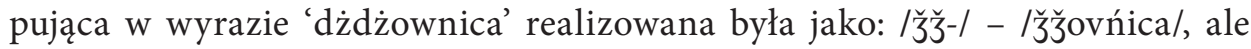
również /亏́-/ - /̧́ovńica/, /źovńića/, /33-/ - /330vńica/, /3-/ - /30vńica/, /ž-/ /žovńica/, /d-/ - /dovńica/,/క̌-/ - /క̌ovńica/. W grupie czterolatków w wymowie triady spółgłoskowej /pšč-/ występującej w wyrazie 'pszczoła’ zaobserwowano 9 różnych realizacji. Były to: /pš-/ - /pšouna/, /sc-/ - /scouna/, /pč-/ - /pčouna/, /psc-/ - /pscouna/, /ps-/ - /psouna/, /ss-/ - /ssouna/, /pc-/ - /pcouna/, /fpč-/ - /fpčouna/, /̌̌-/ - /čouna/.

Dla porównania - w wymowie dzieci trzyletnich odnotowano w przypadku wyrazu 'świeczki' oprócz prawidłowej realizacji /śfí / (Śledziński, 2013, s. 69-70) również /fi -/, /śi -/, /fí-/, /sí-/, /šfi-l, /ć-/, w leksemie 'chrząszcz' w nagłosie - /s-/, /sc-/, /xs-/, /ks-/, z kolei w wygłosie /-sc/, /-s/, /-c/: /sąsc/, /scąs/, /xsąsc/, /sąc/, /xsąs/, /ksąsc/. W wyrazie 'dżdżownica' ani razu nie wystąpiła poprawna reali- 


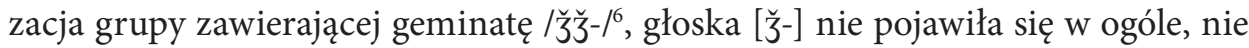
zaobserwowano zatem ani jej hiperpoprawnej realizacji w postaci diady /̌̌ž-/ ani uproszczenia /̌̌-/. W pozycji nagłosu, w miejscu jej wystąpienia pojawiły się następujące spółgłoski: /3-/ - /zovńica/, /zonńica/, /c-/ - /cańica/, /cofńica/, /ź-/ - /źivńica/. W wyrazie 'pszczoła' wystąpiły następujące realizacje triady spółgłoskowej /pšč-l: /c-I, /pc-l, /pč-l, /psc-l, /pšc-l, /sps-I, /špš-/.

$\mathrm{W}$ grupie pięciolatków w wymowie leksemu 'świeca' oprócz prawidłowej realizacji pojawiły się również: /śi-/, /sfi-l, /šfi-/. Nagłos wyrazu 'chrząszcz' realizowany był jako: /xs-I, /č-l, /xč-l, /kšs-/, /x̌s-/, /š-l, /šš-/, /s-/; wygłos /-s/, /-šl, /-ščl,

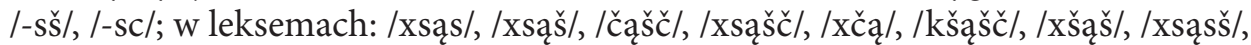

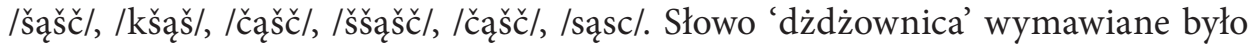

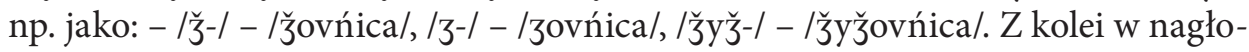
sie leksemu 'pszczoła' pojawiły się następujące realizacje grup: /pč-/, /pś-/, /̌̌č-l, /pš-l, /psc-l, /špšč-/ (tabela 2).

TA BELA 2. Grupy spółgłoskowe zawierające spółgłoski szczelinowe i zwarto-szczelinowe w wymowie dzieci trzy-, cztero- i pięcioletnich

\begin{tabular}{|c|c|c|c|}
\hline Wyraz & $\begin{array}{c}\text { Grupa } \\
\text { spółgłoskowa } \\
\text { w wymowie dzieci } \\
\text { trzyletnich }\end{array}$ & $\begin{array}{c}\text { Grupa } \\
\text { spółgłoskowa } \\
\text { w wymowie dzieci } \\
\text { czteroletnich }\end{array}$ & $\begin{array}{c}\text { Grupa } \\
\text { spółgłoskowa } \\
\text { w wymowie dzieci } \\
\text { pięcioletnich }\end{array}$ \\
\hline 'świeczka' & /fí-l, /śsi -l, /si -l, /ć-l, /šfí-l & /ś-l, /śi -l, /fi -l, /sfí-/ & /śi-l, /sfi -l, /šfi -l. \\
\hline 'chrząszcz' & $/ \mathrm{s}-/, / \mathrm{sc}-/, / \mathrm{xs}-/, / \mathrm{ks}-/$ & /kš-I, /xs-I, /kš-I, /s-I, /ś-/; & 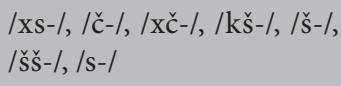 \\
\hline ‘chrząszcz' & $|-s c|,|-s /|-c \mid$, & |-sc|, |-čc|, |-cl, |-nč/, |-ńć| & |-s/, /-š/, /-š̌l, /-sc| \\
\hline 'dżdżownica' & /3-I, /c-l, /3-1 & Iź-I, /zz-l, /3-I, /ž-l, /d- I, /ž-l & /క̌-I, /3-I, /క̌уక̆-I, /сус-I \\
\hline 'pszczoła' & $\begin{array}{l}/ \mathrm{c}-/, / \mathrm{pc}-/, / \mathrm{pč}-/, / \mathrm{psc}-/, \\
/ \mathrm{pšc}-/, / \text { sps- } /, / \text { špš- } /\end{array}$ & 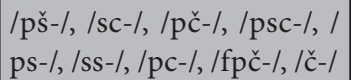 & $\begin{array}{l}/ \mathrm{pč}-/, / \mathrm{pss}-/, / \text { ščl, /špšč/, } \\
/ \mathrm{psc} / / \mathrm{ps} /\end{array}$ \\
\hline
\end{tabular}

ŹróDŁo: Opracowanie własne.

Wymowę dzieci czteroletnich charakteryzuje największe zróżnicowanie w zakresie zjawisk występujących w obrębie jednej grupy spółgłoskowej w tej samej jednostce leksykalnej. We wspomnianej populacji zaobserwować można pojawianie się różnych zjawisk - uproszczeń, substytucji, hiperpoprawności, epentezy, ale także współwystępowanie wymienionych procesów. Zróżnicowanie dotyczy również poszczególnych zjawisk, np. uproszczenie grupy spółgłoskowej /pšč-/ występuje w populacji trzylatków w postaci: /c-/, /pc-/, /pč-/, u czterolatków:

${ }^{6}$ Normatywna realizacja geminat polega na przedłużonej artykulacji spółgłoski tworzącej geminatę, natomiast w przypadku wyrazów typu 'dżdżownica', 'dżdżysty', 'czczy' powszechna jest wymowa zgodna z zapisem, czyli z podwójną spółgłoską (Dunaj, 2006, s. 169). 
/pš-/, /sc-/, /pč-/, /ps-/, /ss-/, /pc-/, /č-/, natomiast w przypadku dzieci pięcioletnich jest to już tylko: /pč-/, /pś-/, /šč/, /pš/. Podobnie analizując pojawiające się w materiale leksykalnym substytucje, najwięcej zróżnicowanych zamian określonej głoski na inną pojawiło się w wymowie dzieci czteroletnich. Na przykład geminata /క̌ž-/ u grupie trzylatków realizowana była jako /3-/, /c-/, /ź-/, w populacji dzieci pięcioletnich jako /3-/, /c-/, natomiast czterolatki wymawiały zamiast głoski [ž] zarówno [3́], [3], [ž], jak i [d]. Owa ilość zróżnicowanych realizacji pojawiających się w obrębie omawianych grup spółgłoskowych dodatkowo wzrasta, gdy weźmie się pod uwagę zjawiska współtowarzyszące wspomnianej substytucji czy wyżej omówionemu uproszczeniu grup konsonantycznych.

Analizując sposoby wymowy grup spółgłoskowych, zauważa się, iż w przypadku wyrazów 'świeczka' czy 'pszczoła' w realizacji triad spółgłoskowych pojawiają się różnice dotyczące zarówno tego, która głoska w wyrazie jest przez dziecko upraszczana, jak i pojawiających się innych, towarzyszących zjawisk językowych. Obserwuje się pewne powtarzające się sposoby wymowy triad konsonantycznych, jednak można również zaobserwować występowanie uproszczeń mających charakter indywidualny (Barlow, 2005, s. 675). W przeprowadzonych wcześniej badaniach nad wymową grup spółgłoskowych wskazano pewnego rodzaju preferencje dotyczące redukcji - i tak np. dzieci niemieckojęzyczne wymawiają pierwszą występującą w wyrazie spółgłoskę, z kolei mówiące w języku hiszpańskim - drugą (Lleó \& Prinz, 1996, s. 37). W przypadku grup spółgłoskowych /śfi-/ oraz /pšč-/ częściej wymawianą spółgłoską była pierwsza głoska wchodząca w skład triady.

\section{Podsumowanie}

Analizując wyniki prezentowanych badań, zauważyć można kilka zjawisk zachodzących w procesie rozwoju języka dzieci trzy-, cztero- i pięcioletnich. Uwagę zwraca znaczna różnica pomiędzy realizacją grup spółgłoskowych w najmłodszej grupie wiekowej oraz w przypadku obu starszych grup. Dotyczy to szczególnie ilości wymawianych przez dzieci elementów spółgłoskowych. Zatem w przypadku trzyletnich użytkowników języka proces redukcji wydaje się dominującym zjawiskiem - w prezentowanych badaniach staje się to szczególnie zauważalne w nagłosie (tabela 3 ).

Uwagę zwraca również wyrównanie wyników w odniesieniu do substytucji oraz uproszczeń wymowy grup spółgłoskowych w wypadku cztero- oraz pięciolatków. Zjawisko staje się tu szczególnie zauważalne w pozycji nagłosowej. Kolejnym zjawiskiem jest wyrównanie wyników w zakresie procentowego występowania substytucji w grupie dzieci pięcioletnich, co może świadczyć 
o rosnącej świadomości i konsekwencji realizacji określonych dźwięków w tej populacji.

TA BELA 3. Procesy zachodzące w realizacji grup spółgłoskowych zawierających głoski szczelinowe i zwarto-szczelinowe w nagłosie, śródgłosie oraz wygłosie w grupie dzieci trzy-, cztero- i pięcioletnich

\begin{tabular}{|l|c|c|c|c|c|c|}
\hline & Trzylatki & & Czterolatki & & Pięciolatki & \\
\hline Nagłos & & & & & & \\
\hline A & 299 & & 599 & & 653 & \\
\hline B & 62 & $21 \%$ & 114 & $19 \%$ & 87 & $13 \%$ \\
\hline C & 53 & $18 \%$ & 35 & $6 \%$ & 17 & $3 \%$ \\
\hline D & 129 & $43 \%$ & 109 & $18 \%$ & 71 & $11 \%$ \\
\hline Śródgłos & & & & & & \\
\hline A & 122 & & 276 & & 290 & \\
\hline B & 25 & $20 \%$ & 37 & $13 \%$ & 33 & $11 \%$ \\
\hline D & 8 & $7 \%$ & 2 & $1 \%$ & 0 & $0 \%$ \\
\hline Wygłos & & $7 \%$ & 6 & $2 \%$ & 4 & $1 \%$ \\
\hline A & 44 & & & & & \\
\hline B & 21 & $48 \%$ & 15 & $17 \%$ & 10 & $12 \%$ \\
\hline C & 2 & $5 \%$ & 7 & $8 \%$ & 2 & $2 \%$ \\
\hline D & 4 & $9 \%$ & 8 & $9 \%$ & 3 & $4 \%$ \\
\hline
\end{tabular}

ŹróD£O: Opracowanie własne.

Warto zwrócić również uwagę na ilość grup spółgłoskowych zrealizowanych poprawnie w każdej z grup wiekowych. Nagłosowe kompleksy konsonantyczne u grupie dzieci trzyletnich zgodnie z wymową normatywną dla języka polskiego realizowało $15 \%$ populacji - przy czym należy podkreślić, iż jako normę rozwojową traktuje się występujące w tej grupie wiekowej substytucje głosek szczelinowych i zwarto-szczelinowych, przedniojęzykowo-dziąsłowych oraz przedniojęzykowo-zębowych, takich jak [š, ž, č, ̌̌] oraz [s, z, c, z]. W populacji dzieci czteroletnich połączenia konsonantyczne zgodnie z normą językową wymawiało 53\% osób, z kolei w grupie pięciolatków 71\%. Mniejsze różnice obserwuje się natomiast $\mathrm{w}$ sposobie realizacji śródgłosu oraz wygłosu. Zgodnie z normą językową w grupie dzieci trzyletnich kompleksy spółgłoskowe zawierające sąsiedztwo głosek szczelinowych i zwarto-szczelinowych wymawiało $49 \%$, w populacji czterolatków - 77\%, natomiast wśród pięciolatków - 86\%. W wygłosie wyrazów $26 \%$ trzylatków realizowało połączenia konsonantyczne zgodnie z normą językową. 
W grupie czterolatków sytuacja taka miała miejsce w przypadku 53\% badanych, w gronie pięciolatków było to $72 \%$.

Istotnym zjawiskiem wydaje się również wspomniana wcześniej produktywność czterolatków polegająca na towarzyszeniu realizacji zbitek spółgłoskowych zróżnicowanych zjawisk oraz współwystępowaniu kilku procesów jednocześnie, co należy do istotnych aspektów charakterystycznych dla wymowy dzieci w tej grupie wiekowej.

\section{Bibliografia}

Barlow, J.A. (2003). Asymmetries in the Acquisition of Consonant Clusters in Spanish. Canadian Journal of Linguistics / Revue canadienne de linguistique, 48(3/4), 179-210.

BARLOW, J.A. (2005). Phonological change and the representation of consonant clusters in Spanish: A case study. Clinical Linguistics \& Phonetics, 19(8), 659-679.

Bee, H. (2004). Psychologia rozwoju człowieka (J. Gilewicz, \& A. Wojciechowski, tłum.). Poznań: Wydaw. Zysk i S-ka.

BINKUŃsKa, E. (2017). Grupy spółgłoskowe w logopedycznych próbach diagnostycznych. W: S. Milewski, K. Kaczorowska-Bray, \& B. Kamińska (red.), Studia logopedyczno-lingwistyczne. Ksiega jubileuszowa z okazji 70-lecia urodzin Profesora Edwarda Łuczyńskiego (s. 295-311). Gdańsk: Harmonia Universalis.

Bryndal, M. (2015). Fonologiczna interpretacja procesów doskonalenia wymowy dziecięcej na tle współczesnych teorii fonologicznych. Gliwice: Wydaw. Komlogo Piotr Gruba.

Czaplewska, E. (2012). Diagnoza zaburzeń rozwoju artykulacji. W: E. Czaplewska, \& S. MilewSKI (red.), Diagnoza logopedyczna. Podręcznik akademicki (s. 65-120). Sopot: Gdańskie Wydaw. Psychologiczne.

Demuth, K., \& Kenoe, M. (2006). The Acquisition of Word-final Clusters in French. Catalan Journal of Linguistics, 5, 59-81.

DoŁęGA, Z. (2003). Promowanie rozwoju mowy w okresie dzieciństwa - prawidłowości rozwoju, diagnozowanie i profilaktyka. Katowice: Wydaw. Uniwersytetu Śląskiego.

DunaJ, B. (2006). Zasady poprawnej wymowy polskiej. Język Polski, LXXXVI, 161-172.

Dyszak, A., Laskowska, E., \& ŚwiĘCicka, M. (1997). Fonetyczny i fonologiczny opis wspótczesnej polszczyzny. Skrypt dla studentów filologii polskiej. Bydgoszcz: Wydaw. Uczelniane Wyższej Szkoły Pedagogicznej.

Gwozdiew, A.N. (2007). Woprosy izuczenija dietskoj reczi. Moskwa: Izdatielstwo Akademii Pedagogiczeskich Nauk.

KaCZMAReK, L. (1982). Nasze dziecko uczy się mowy. Lublin: Wydaw. Lubelskie.

Kania, J.T. (2001). Szkice logopedyczne. Lublin: Polskie Towarzystwo Logopedyczne. Zarząd Główny.

Kielar-Turska, M. (2012). Rozwój sprawności językowych i komunikacyjnych. W: E. CzaplewSKa, \& S. Milewski (red.), Diagnoza logopedyczna. Podręcznik akademicki (s. 15-63). Sopot: Gdańskie Wydaw. Psychologiczne.

Krajna, E. (2002). Doskonalenie artykulacji u dzieci przedszkolnych - wybrane zagadnienia. Logopedia, 31, 27-52. 
Krajna, E. (2008). 100-wyrazowy test artykulacyjny. Podręcznik. Gliwice: Wydaw. Komlogo Piotr Gruba.

Krasowicz-Kupis, G. (2004). Rozwój świadomości językowej dziecka. Teoria i praktyka. Lublin: Wydaw. Uniwersytetu Marii Curie-Skłodowskiej.

Lleó, C., \& Prinz, M. (1996). Consonant Clusters in Child Phonology and the Directionality of Syllable Structure Assignmemt. Journal of Child Language, 23, 31-56.

Łoвacz, P. (1996). Polska fonologia dziecięca. Studia fonetyczo-akustyczne. Warszawa: Wydaw. Energeia.

Łobacz, P.: (2005). Prawidłowy rozwój mowy dziecka. W: T. GaŁkowski, E. SzeląG, \& G. JAstrzęBowska (red.), Podstawy neurologopedii. Podręcznik akademicki (s. 231-268). Opole: Wydaw. Uniwersytetu Opolskiego.

Madelska, L. (2005). Słownik wariantywności fonetycznej współczesnej polszczyzny. Kraków: Collegium Columbinum.

MiLEWSKI, S. (1998). Nagłosowe grupy spółgłoskowe w tekstach mówionych dzieci w wieku przedszkolnym. W: I. NowAKowsKa-KemPNA (red.), Logopedia jako nauka interdyscyplinarna - teoretyczna i stosowana (s. 175-211). Katowice: Wydaw. Uniwersytetu Śląskiego.

Milewski, S. (1999). Lingwistyczne i dydaktyczne aspekty analizy fonemowej. Lublin: Wydaw. Uniwersytetu Marii Curie-Skłodowskiej.

MiLewsKi, S. (2001). Śródgłosowe grupy spółgłoskowe w tekstach mówionych dzieci w wieku przedszkolnym. W: S. Grabias (red.), Zaburzenia mowy. T. 1 (s. 216-252). Lublin: Wydaw. Uniwersytetu Marii Curie-Skłodowskiej.

Milewski, S. (2005). Grupy spółgłoskowe w języku mówionym dzieci przedszkolnych. Logopeda. Czasopismo internetowe, 1(1), 5-32.

MilewsKi, S. (2017). Grupy spółgłoskowe jako problem logopedyczny. W: S. MilewsKi, K. KaCzorowsKa-Bray, \& B. KamiŃsKa (red.), Studia logopedyczno-lingwistyczne. Księga jubileuszowa z okazji 70-lecia urodzin Profesora Edwarda Euczyńskiego (s. 269-294). Gdańsk: Harmonia Universalis.

Porayski-Pomsta, J. (2015). O rozwoju mowy dziecka. Dwa studia. Warszawa: Dom Wydawniczy „Elipsa”.

Przybyla, O. (2013). O kinestezji, praksji oralnej i koordynacji w perspektywie integrującej. W: J. Panasiuk, \& T. Woźniak (red.), Język-człowiek-społeczeństwo (s. 791-811). Lublin: Wydaw. Uniwersytetu Marii Curie-Skłodowskiej.

Przybyla, O. (2015). Motoryczne zdolności koordynacyjne w świetle badań nad mową. W: K. Kaczorowska-Bray, \& S. Milewski (red.), Metodologia badań logopedycznych (s. 322-363). Gdańsk: Wydawnictwo Harmonia Universalis.

RocŁawski, B. (1986a). Poradnik fonetyczny dla nauczycieli. Warszawa: Wydawnictwa Szkolne i Pedagogiczne.

RoCŁAWSKI, B. (1986b). Zarys fonologii, fonetyki, fonotaktyki i fonostatystyki wspólczesnego języka polskiego. Gdańsk: Wydaw. Uczelniane Uniwersytetu Gdańskiego.

So£tys-Chmielowicz, A. (1998). Wymowa dzieci przedszkolnych. Lublin: Wydaw. Uniwersytetu Marii Curie-Skłodowskiej.

SoŁtys-Chmielowicz, A. (2005). Zaburzenia artykulacji. W: T. GaŁkowski, E. SzeląG, \& G. Jastrzęвowska (red.), Podstawy neurologopedii. Podręcznik akademicki (s. 421-474). Opole: Wydaw. Uniwersytetu Opolskiego.

So£tys-Chmielowicz, A. (2008). Zaburzenia artykulacji. Teoria i praktyka. Kraków: Impuls.

ŚLEDZIŃsKi, D. (2010). Analiza struktury grup spółgłoskowych w nagłosie oraz w wygłosie wyrazów w języku polskim. Kwartalnik Językoznawczy, 3-4, 61-84.

ŚLEDZIŃSKI, D. (2013). Podział korpusu tekstów na sylaby - analiza polskich grup spółgłoskowych. Kwartalnik Językoznawczy, 3, 48-100. 
Wó tтowiczowa, J. (1993). Logopedyczny zbiór wyrazów. Warszawa: Wydawnictwa Szkolne i Pedagogiczne.

ZARĘBINA, M. (1965). Kształtowanie się systemu językowego dziecka. Wrocław-Warszawa-Kraków: Zakład Narodowy im. Ossolińskich.

ZaręBina, M. (1994). Język polski w rozwoju jednostki. Gdańsk: Wydaw. Glottispol.

ZGóŁkowa, H. (2016). Słownictwo dzieci w wieku przedszkolnym w latach 2010-2015. Poznań: Wydaw. Uniwersytetu Adama Mickiewicza.

ZGóŁKowA, H., \& BUŁCZYŃsKa, K. (1987). Słownictwo dzieci w wieku przedszkolnym: listy frekwencyjne. Poznań: Wydaw. Uniwersytetu Adama Mickiewicza.

Zydorowicz, P. (2010). Consonant clusters across morpheme boundaries: polish morphonotactic inventory and its acquisition. Poznań Studies in Contemporary Linguistics, 46(4), 565-588. 